8.

Derecho procesal penal 



\title{
Sistema ACUSATORIO DE JUSTICIA PENAL Y PRINCIPIO DE OBLIGATORIEDAD DE LA ACCIÓN PENAL
}

[Adversary System of Criminal Justice and Principle of Mandatory Prosecution of Criminal Proceedings]

\author{
Manuel Rodríguez VegA* \\ Universidad de las Américas, Santiago de Chile
}

\begin{abstract}
RESUMEN
En el artículo se revisa y confirma el marcado carácter acusatorio del actual proceso penal chileno y su relación con su incidencia en la eficacia del principio de obligatoriedad de la acción penal que rige las actuaciones del Ministerio Público. Se desarrollan los corolarios de que una mayor intervención de los órganos jurisdiccionales para evitar las actuaciones de la Fiscalía desconocedoras de dicho principio de obligatoriedad, puedan acarrear consecuencias en la estructura acusatoria del proceso.
\end{abstract}

\section{Palabras clave}

Obligatoriedad - Sistema acusatorio - Principio acusatorio - Ministerio Público.

\begin{abstract}
This article analyses and confirms the strong adversarial character of the present Chilean criminal procedure and its relationship with and effect on the principle of mandatory prosecution of the criminal proceedings that governs the proceedings of the Attorney General's Office. The corollaries for a further intervention of the judicial bodies to avoid that legal actions of the Attorney General's Office that are not aware of said principle of mandatory prosecution, may entail consequences on the adversary structure of the process.

KEYWORDS

Mandatoriness - Adversarial system - Adversary principle - Attorney General's Office.
\end{abstract}

ReCiBIDo el 23 de febrero y ACEPTADo el 30 de mayo de 2013

* Magíster en Derecho Penal por la Universidad de Talca, candidato a doctor en Derecho por la Universidad de Chile, juez de garantía de Santiago, profesor de Derecho penal en la Universidad de las Américas. Dirección postal: Avda. Pedro Montt 1606, edificio F, piso 9², Santiago, Chile. Correo electrónico: merodrig@uc.cl 


\section{INTRODUCCIÓN}

Habitual se ha vuelto en el foro nacional dudar de la fuerza y contenido que el Ministerio Público da a la acción penal ejercida ante los tribunales competentes, cuestionándose su prevalimiento de diversos vacíos e imprecisiones del legislador, para no ejercer la acción penal, siendo ésta procedente a la vista de la prueba reunida ${ }^{1}$, o para devaluar la pretensión punitiva contenida en sus requerimientos y acusaciones ${ }^{2}$, transformando esto último en una eficiente herramienta de negociación con el imputado y su defensa.

Con tales prácticas se infringe el principio de obligatoriedad de la acción penal que pesa sobre el Ministerio Público (artículo 166 inciso $2^{\circ} \mathrm{CPP} .{ }^{3}$ ), si entendemos por tal el deber del Ministerio Público de iniciar, sostener y perseverar en la persecución penal de todo delito del cual tome conocimiento, sin que pueda suspenderla, interrumpirla o hacerla cesar a su discreción ${ }^{4}$.

${ }^{1}$ Tales reparos se han presentado principalmente a raíz de la imposibilidad de la víctima-querellante de ejercer la acción penal mediante la acusación particular si previamente el Ministerio Público ha omitido formalizar cargos contra el imputado-querellado. Al respecto, el Tribunal Constitucional ha emitido diversos pronunciamientos, v.gr.: rol No 815-07 de 19 de agosto de 2008; rol N 1337-09 de 20 de agosto de 2009; rol No 1.467-2009 de 29 de diciembre de 2009; rol $\mathrm{N}^{\circ} 1341-2009$ de 15 de abril de 2010; rol $\mathrm{N}^{\circ}$ 1380-2009 de 3 de noviembre de 2009; rol $\mathrm{N}^{\circ} 1445-09$ de 29 de enero de 2010; rol No 1404-09 de 18 de mayo de 2010; rol No 1394-09 de 13 de julio de 2010; rol $\mathrm{N}^{\circ} 1542-09$ de 31 de agosto de 2010; y rol N $1484-2009$ de 5 de octubre de 2010. Un examen de la evolución de la jurisprudencia constitucional de esta materia se ve en: Piedrabuena Richard, Guillermo, Rol del Ministerio Público en el nuevo proceso penal, en Revista Chilena de Derecho, 30 (2003) 1, pp. 11-21; y Jurisprudencia del Tribunal Constitucional sobre normas del Código Procesal Penal, en Revista de Derecho del Consejo de Defensa del Estado, 21 (junio de 2009), pp. 69-94.

${ }^{2}$ Para un acabado y crítico estudio sobre estas prácticas, véase: Del Río FerretTi, Carlos, Proceso penal, consenso de las partes y enjuiciamiento jurisdiccional (Santiago, Librotecnia, 2009).

3 "Cuando el Ministerio Público tomare conocimiento de la existencia de un hecho que revistiere caracteres de delito, con el auxilio de la policia, promoverá la persecución penal, sin que pueda suspender, interrumpir o hacer cesar su curso, salvo en los casos previstos en la ley."

${ }^{4}$ MaIer, Julio, Derecho procesal penal argentino (Buenos Aires, Hammurabi, 1989), I, B, p. 548, indica que este principio de "legalidad", desde un punto de vista negativo, significa que ningún criterio de oportunidad - político-utilitario por conveniencia práctica, económica, temporal, etc.- autoriza, en principio, a prescindir de la persecución penal frente a la noticia de la comisión de un hecho punible. Roxin, Claus, Derecho procesal penal (traducción castellana de G. Córdoba y D. Pastor, Buenos Aires, Editores del Puerto, 2000), p. 89, que también llama a este principio de legalidad, lo define como el deber de realizar las investigaciones cuando existe la sospecha de que se ha cometido un hecho punible y, por otra parte, de formular la acusación cuando después de las 
Pero aquellos reparos también han alcanzado a los tribunales, y en particular, a los Juzgados de Garantía, reprochándoseles no actuar oficiosamente y en base a los principios generales del derecho procesal y penal, a falta de regla expresa que los habilite, para atajar o remediar las decisiones discrecionales del persecutor público que menguen el principio de obligatoriedad55.

investigaciones sigue existiendo esa sospecha vehemente. En la definición propuesta en el texto se incluye lo que algunos iusprocesalistas tratan como el desdoblamiento del principio examinado en "promoción necesaria" e "irrefragabilidad", así, ClaRIÁ OLMEDo, Jorge, Derecho procesal penal (Buenos Aires, Rubinzal-Culzoni, s.d.) I, pp. 234235, alude con el primero a la promoción del proceso una vez tomado conocimiento de un hecho que encuadra con una norma penal, y con el segundo a la mantención del ejercicio de la jurisdicción hasta obtener un pronunciamiento definitivo sobre el fondo. CAFFerata Nores, José, El proceso penal según el sistema constitucional, ahora, en EL MISmo, Cuestiones actuales sobre el proceso penal ( $3^{\mathrm{a}}$ edición, Buenos Aires, Editores del Puerto, 2000), p. 23, denomina la obligatoriedad en estos dos momentos como "inevitabilidad" e "irretractabilidad", respectivamente. Otros autores como MAIER, J., Derecho procesal penal argentino, cit. (n. 4), p. 548; Horvitz Lennon, María Inés - López Masle, Julián, Derecho procesal penal chileno (Santiago, Editorial Jurídica de Chile, 2005), I, p. 46; y Cerda San Martín, Rodrigo - Hermosilla IriarTE, Francisco, El Código Procesal Penal. Comentarios, concordancias y jurisprudencia ( $2^{\text {a }}$ edición, Santiago, Librotecnia, 2006), p. 189, también comprenden en el principio de legalidad a los principios de "promoción necesaria" y de "irretractabilidad". Como se verá, hemos optado por el antagonismo obligatoriedad-discrecionalidad en el ejercicio de la acción penal, por su mayor precisión conceptual y neutralidad terminológica, siguiendo con ello a Díez-PICAzo, Luis María, El poder de acusar, Ministerio Fiscal y constitucionalismo (Barcelona, Ariel, 2000), p. 13. A fin de sortear distracciones, no hablaremos tampoco de "principio de necesidad", "indefectibilidad" o "nulla poena sine iudicio", que ciertos tratadistas asimilan al de obligatoriedad, pues con aquéllos se suele aludir a algo distinto, a saber, que "el proceso penal es obligatorio para averiguar la infracción criminal, descubrir al autor, juzgarle y, sobre todo, imponer la pena”, PRIETOCastro, Leonardo - Gutiérrez de Cabiedes, Eduardo, Derecho procesal penal (2a edición, Madrid, Tecnos, 1982), p. 90, o en otras palabras, para referirse a la necesidad del Estado de acudir al proceso para hacer valer el ius puniendi de que es titular. En este sentido véanse: Gómez Orbaneja, Emilio - Herce Quemada, Vicente, Derecho procesal penal (10a edición, Madrid, Artes Gráficas y Ediciones, 1987), p. 2; y SERRA Domínguez, Manuel, Estudios de Derecho procesal (Barcelona, Ariel, 1969), pp. 759760. Montero Aroca, Juan - Ortells Ramos, Manuel - Gómez Colomer, J., Derecho jurisdiccional. Parte general (2a edición, Barcelona, Bosch, 1989), I, pp. $497-$ 498 , incluyen el aspecto comentado junto a lo que nosotros entendemos por obligatoriedad de la acción penal en el principio de necesidad procesal. Sobre el principio de indefectibilidad en el ordenamiento nacional, véase: NúñEZ VÁsQUEZ, J. Cristóbal, Tratado del proceso penal y del juicio oral (Santiago, Editorial Jurídica de Chile, 2003), I, pp. 23-24.

${ }^{5}$ Por ejemplo: Del Río Ferretti, Carlos, El principio del consenso de las partes en el proceso penal y enjuiciamiento jurisdiccional: aclaraciones conceptuales necesarias, en Revista Chilena de Derecho, 35 (2008) 1. 
Pues bien, tales cuestionamientos deben examinarse con mesura y visión de conjunto, precaviendo no romper el delicado equilibrio que logró la nueva regulación adjetiva en materia penal entre la eficacia de la persecución y el respeto a las garantías del perseguido. En efecto, el despojar a los tribunales de los deberes de investigar y acusar para adjudicárselos a un nuevo organismo como el Ministerio Público puede catalogarse como el primer y principal logro de la reforma a nuestro sistema de justicia penal emprendida en Chile a fines del siglo XX. Tal escisión ha permitido a los tribunales avocarse a labores propiamente jurisdiccionales, no sólo de resolver sobre la inocencia o culpabilidad del acusado en juicio, sino de cautelar sus garantías durante las etapas previas, y posteriores, al enjuiciamiento, de manera de transformarse en un desinteresado vigilante de la legalidad de las actuaciones del Ministerio Público.

Azuzar por elevar los niveles de entrometimiento de los tribunales frente a la pasividad del acusador público, corre el riesgo de vulnerar un diseño constitucional nítido en cuanto a los roles del Ministerio Público y de los órganos jurisdiccionales al interior del proceso, y sobre todo de menoscabar el novedoso esquema acusatorio por el que se inclina el conjunto de nuestro proceso penal.

A ello entonces nos embarcamos en los apartados siguientes, esto es, dilucidar cómo la pretensión de una mayor injerencia de nuestros tribunales para cautelar que las actuaciones del Ministerio Público no descuiden o vulneren el principio de obligatoriedad de la acción penal que los rige, de prosperar, puede menguar seriamente el carácter acusatorio de nuestro proceso, y consiguientemente la garantía de un enjuiciamiento imparcial -en las distintas etapas del proceso- que aquél garantiza.

\section{Principio aCUSATORIO y Sistema ACUSATORIO}

Resulta indispensable demorarnos aquí para precisar qué discerniremos como sistema acusatorio de enjuiciamiento penal, pues parte no menor de este artículo reside en constatar la tensión existente al interior del binomio supervisión judicial del principio de obligatoriedad de la acción penal y la acusatoriedad del proceso.

En un primer orden, evitaremos asimilar lo "acusatorio" a lo "adversarial",

\footnotetext{
${ }^{6}$ Acerca de ambos conceptos, WoIschnik, Kai - WoIschnik, Jan, Las reformas procesales penales en América Latina, en MAIER, Julio y otros (coordinadores), Las reformas procesales penales en América Latina (Buenos Aires, Ad Hoc, 2000), p. 868. El uso de los términos "adversarial” y "acusatorio" como sinónimos supone, respecto del último, alejarse de su sentido semántico original, pues el término "acusatorio", en su significado latín original (accusare o acusar) no se refiere a la forma de diligenciar las
} 
sin perjuicio de los puntos de encuentro indiscutiblemente existentes, atendido el fuerte contenido ideológico o político que se le suele endosar a este último, principalmente su afinidad con la pasiva ideología liberal del laissez-faire $e^{7}$, lo que puede desviarnos del punto específico que nos interesa abrazar en esta parte de la investigación, esto es, la necesidad y relevancia de la pasividad y distancia del órgano jurisdiccional de las posiciones de las partes, como garantía de un tratamiento y juzgamiento imparcial ${ }^{8}$.

En segundo término, distingamos entre el "principio acusatorio" y el "sistema acusatorio". El primero no es más que uno de los principios configuradores del proceso acusatorio que regula aspectos bien específicos de éste, cuyo contenido se ciñe a la separación de la función de acusación de la de enjuiciamiento, funciones que deben ser atribuidas a órganos distintos, y por tal motivo la acusación -el objeto del proceso- ha de ser planteada en juicio por un sujeto distinto del juez?. Como es bien sabido, los orígenes del

pruebas sino exclusivamente a que el procedimiento (plenario) sólo puede iniciarse en base a una acusación. En esencia, la antinomia proceso adversarial/instruccionista es distinta a la antinomia acusatorio/inquisitivo; por su parte, Goldstein, Abraham S., Reflections on Two Models: Inquisitorial Themes in American Criminal Procedure, en Stanford Law Review, 26 (mayo de 1974), pp. 1016-1017, considera el término "adversarial" como referido a un método de resolver disputas que toma sus contornos del juicio contencioso, mientras la palabra "acusatorio" es un clásico modelo de procedimiento que comprende no sólo el juicio adversarial, sino asume un equilibrio social que no debe ser ligeramente perturbado, y asigna gran valor social a mantener el estado fuera de las disputas, especialmente cuando pueden seguir estigmas y sanciones a su intervención; Lafave, Wayne y otros, Criminal Procedure ( $5^{a}$ edición, s. l., West, 2009), pp. 43-45, distinguen entre la adjudicación adversarial y las cargas acusatorias, aludiendo con lo primero a la determinación de los hechos y el derecho por la autoridad encargada de su adjudicación a la luz de los materiales presentados por las partes, y con lo último, a la distribución de cargas entre las partes con respecto a la adjudicación de culpabilidad.

${ }^{7}$ Damaska, Mirjan, Las caras de la justicia y el poder del Estado. Análisis comparado del proceso civil (traducción castellana de A. Morales Vidal, Santiago, Editorial Jurídica de Chile, 2000), cap. $3^{\circ}$, pp. 125 ss.

${ }^{8}$ Desde luego nuestro enfoque se dirige hacia el distanciamiento del tribunal de la parte acusadora, como garantía de enjuiciamiento del imputado, pues respecto a éste el rol conservador y garante del órgano jurisdiccional, y de sobremanera en la etapa de instrucción y preparación del juicio, requerirá permanentemente abandonar su letargo frente a vulneraciones de los derechos del justiciable que no sean advertidas o invocadas incluso por su defensa.

${ }^{9}$ De la Oliva Santos, A. y otros, Derecho procesal penal (4a edición, Madrid, Edición Centro de Estudios Areces s.a., 1999), p. 43, identifican el principio acusatorio como el "criterio configurador del proceso penal según el cual se necesita una acusación -la imputación a una o varias personas concretas de unos determinados hechos- para el inicio de la fase de plenario o juicio oral y para una sentencia de condena"; ARMENTA 
principio acusatorio, así formulado, se remontan a los postulados iluministas concretados con posterioridad a la revolución francesa que buscaban dejar atrás el principio inquisitivo del Ancién Régime, pero sin retrotraerse a los modelos acusatorios históricos, desdoblando entonces las funciones estatales de acusar y juzgar en dos autoridades diversas, conocido como principio acusatorio formal ${ }^{10}$.

El sistema acusatorio, en cambio, implica la vigencia de principios procesales y la aplicación de reglas relativas tanto a la sustancia como a la configuración externa del proceso penal, y no se conforma con la separación acusador-juzgador ni la imparcialidad en el enjuiciamiento a que éste atien$\mathrm{de}^{11}$. Se mencionan entre dichos principios y reglas, el principio de contradicción, la igualdad de armas entre las partes, la separación de funciones de investigación y decisión, la proscripción de la reformatio in peius, y también, el principio acusatorio. El sistema procesal acusatorio supone entonces una gama de principios y reglas que sumadas dan por resultado la configuración total del proceso $^{12}$.

Deu, Teresa, Principio acusatorio y Derecho penal (Barcelona, Bosch, 1995), pp. 39 y 83 , habla de sistema acusatorio o proceso inspirado por el principio acusatorio, residiendo su esencia "no tanto en la estricta separación entre quien juzga y acusa, sino en la necesidad ineludible de una acusación previa”.

${ }^{10}$ La parcelación de corte histórico-cronológico recurrente en la doctrina europeocontinental y latinoamericana, que distingue procedimientos acusatorio puro, inquisitivo, y acusatorio formal, reformado o mixto, amén de dar lugar a una excesiva simplificación histórica y al olvido de los diversos grados de vigencia de estos grandes modelos respecto de los distintos segmentos de la sociedad, como nos previene BINDER, Alberto, Introducción al Derecho procesal penal (2a edición Buenos Aires, Ad Hoc, 2004), pp. 62 ss., adolece de un parco poder explicativo del estado y características de los sistemas iusprocesales modernos, los que en su amplia mayoría pueden catalogarse, a grandes rasgos, como mixtos, al residir la instrucción y acusación penal en manos públicas, pero distintas del órgano juzgador. Para un acabado desarrollo histórico-político de dicha evolución, véanse: Esmein, A., A History of Continental Criminal Procedure. With Special Reference to France (Boston, Little Brown and Company, 1913); y Maier, J., Derecho procesal penal argentino, cit. (n. 4), pp. 17 ss. Para el interesado en los orígenes del proceso adversarial penal en el common law, véase: LANGBein, John H., The Origins of Adversary Criminal Trial (Oxford, N. Y., Oxford University Press, 2005).

${ }^{11}$ De la Oliva, A. y otros, cit. (n. 9), pp. 42-43.

${ }^{12}$ Por ejemplo, Bettiol, Giuseppe, Instituciones de derecho penal y procesal (traducción castellana de F. Gutiérrez-Alviz y Conradi, Barcelona, Bosch, 1977), p. 279, enuncia como caracteres fundamentales del proceso acusatorio "la plena publicidad de todo el procedimiento; la libertad personal del acusado hasta la condena definitiva; la igualdad absoluta de los derechos y los poderes entre el acusador y el acusado; la pasividad del juez en la recogida de las pruebas tanto de imputación como en descargo; la continuidad del contexto; la síntesis en todo el procedimiento"; ANDRÉs IBÁÑEz, Perfecto, Por un Ministerio Público "dentro de la legalidad", en Nueva Doctrina Penal 
Por nuestra parte, lejos de pretender agobiar con una nueva concepción del sistema acusatorio, más bien nos interesa resaltar la necesidad que la doctrina ha destacado de reproducir en todas las instancias del proceso $-\mathrm{y}$ no sólo en el específico momento de la introducción del objeto del juicio-, el esquema actus trium personarum ${ }^{13}$, propio de un modelo acusatorio de enjuiciamiento, así como la pasividad que esa estructura conlleva para el juez, principalmente en relación a la actividad requirente o de cargo, de manera de garantizar en todo el proceso el máximo la imparcialidad e independencia del juez al resolver los distintos requerimientos del acusador público que puedan afectar derechos del investigado o imputado ${ }^{14}$.

(Buenos Aires, Editores del Puerto, 1998), pp. 465-466, explica que "sólo hay proceso acusatorio en presencia de un juez tercero, llamado a decidir una contienda entre partes, efectivamente regida por el principio de contradicción, materializado éste en un juicio oral y público, decidido mediante valoración en conciencia, suficientemente motivada, de -sólo- lo que en él resulte probado"; Gómez Colomer, Juan Luis, La constitucionalización del proceso penal español, ahora, en el El Mismo, El proceso penal en el Estado de Derecho. Diez estudios doctrinales (Lima, Palestra Editores, 1999), p. 16, afirma como connatural al sistema acusatorio formal el juicio con jurado; FerRAJOLI, Luigi, Derecho y razón. Teoría del garantismo penal ( $5^{a}$ edición, Madrid, Trotta, 2001), pp. 564 y 567, sostiene "que se puede llamar acusatorio a todo sistema procesal que concibe al juez como un sujeto pasivo rígidamente separado de las partes y al juicio como una contienda entre iguales iniciada por la acusación, a la que compete la carga de la prueba, enfrentada a la defensa en un juicio contradictorio, oral y público y resuelta por el juez según su libre convicción”. En este modelo acusatorio, aclara el autor, la separación de juez y acusación es el elemento más importante de todos sus elementos constitutivos, como presupuesto estructural y lógico de todos los demás.

${ }^{13}$ Estructura representada usualmente como un triángulo equilátero o isósceles, con el juez ocupando el vértice superior, y las partes ocupando en el mismo nivel los dos vértices inferiores. BINDER, Alberto M., Ideas y materiales para la reforma de la justicia penal (Buenos Aires, Ad Hoc, 2000), p. 96, utiliza esta figura en sentido diverso, representando la estructura del proceso acusatorio como un triángulo cuya base sería el juicio. El proceso inquisitivo correspondería exactamente a la figura invertida, como está invertida la lógica esencial del proceso: su base más amplia está formada por los actos iniciales y la actividad probatoria va disminuyendo en la medida que se acerca al juicio.

${ }^{14}$ Como un espaldarazo a la imperiosa necesidad de llevar la adversarialidad a la etapa de instrucción, los autores han destacado la imposibilidad material del Juez de instrucción para actuar imparcialmente cuando decide acerca de la necesidad de las medidas de investigación y, al mismo tiempo, acerca de la legalidad de las medidas que personalmente considera necesarias, cfr. Bovino, Alberto, Problemas del Derecho procesal penal contemporáneo (Buenos Aires, Editores del Puerto, 1998), p. 7; Binder, Alberto, Funciones y disfunciones del Ministerio Público Penal, ahora, en Bustos Ramírez, Juan (director), El Ministerio Público (Santiago, Conosur, 1995), p. 186; BINDER, A., Introducción, cit. (n. 10), p. 239 e Ideas, cit. (n. 13), p. 98, donde destaca que esta división de funciones en la investigación preliminar acentúa el carácter acusatorio 
del sistema; MAIER, Julio, Democracia y administración de justicia penal en Iberoamérica, en AA.VV., Reformas procesales en América Latina (Santiago, Corporación de Promoción Universitaria, 1993), pp. 42-43; Moreno Catena, Víctor, Presente y futuro del proceso penal español, en Revista de Derecho y Jurisprudencia, 96 (1999) 2, p. 89; Cafferata Nores, José, Imparcialidad del juez, en El mismo, Cuestiones actuales sobre el proceso penal ( $3^{\text {a }}$ edición, Buenos Aires, Editores del Puerto, 2000), pp. 136 ss.; OrTells Ramos, Manuel, Cuatro aproximaciones al nuevo proceso penal chileno desde la perspectiva del proceso penal en paises de la Unión Europea, en AA.VV., El nuevo proceso penal chileno (Facultad de Ciencias Jurídicas y Sociales. Departamento de Derecho Procesal, Universidad de Concepción, 2000), pp. 307-344; Gandulfo, Eduardo, Principios del Derecho procesal penal en el nuevo sistema de procedimiento chileno, en Revista de Derecho de la Universidad Católica de Valparaiso, 20 (1999), pp. 415-474; Solari Peralta, Tito, Presupuestos teóricos del Ministerio Público, en Revista de Derecho de la Universidad Católica de Valparaíso, 20 (1999), p. 481; Duce, Mauricio - Riego, Cristián, Proceso penal (Santiago, Editorial Jurídica de Chile, 2009), p. 105; Horvitz Lennon, María Inés, Ministerio Público y selectividad, en Pena y Estado. Revista Latinoamericana de Politica Criminal, 2 (1997) 2, p. 112. El Código Procesal Penal modelo para Iberoamérica, en su "Exposición de Motivos", recogió estas ideas al afirmar que "nadie es buen guardián de sus propios actos, esto es, quien está comprometido con la eficiencia de una investigación de motivos no puede ser, al mismo tiempo, quien controla el limite de sus poderes". Del análisis de la jurisprudencia del Tribunal Europeo de Derechos Humanos se ha concluido que "la jurisprudencia europea se niega a aislar la fase del juicio y considera que el respeto de las garantías de un proceso "justo", en el sentido del artículo 6 del Convenio, debe apreciarse globalmente e implica especialmente una cierta igualdad de armas desde la fase preparatoria. Añádase a ello que en la mayor parte de los países europeo-continentales ha comenzado a primar, de hecho o de derecho, la investigación realizada por el Ministerio Fiscal, a reserva de volver a introducir a veces el control de un juez, colocado esta vez en posición de árbitro, Delmas-Marty, Mireille (directora), Procesos penales de Europa (traducción castellana de P. Morenilla A., Zaragoza, Edijus, 2000), pp. 35 y 43-44. De ese modo, la atribución de la competencia para instruir las causas penales al Ministerio Público se ha fundamentado en Alemania, Italia y Portugal, en la siguiente consideración: "la instrucción por un Juez es una institución netamente inquisitiva, por lo que es incompatible con el proceso penal propio de un Estado de Derecho, el cual, se dice, exige la más amplia vigencia del principio acusatorio, contribuyéndose con ello decisivamente a limitar de manera evidente los amplísimos poderes investigadores del Juez de Instrucción en la fase de averiguación o sumarial del proceso penal clásico, bien inquisitivo, bien inquisitivo formal o mixto, acercando la figura del Juez instructor más al papel de árbitro, conforme al modelo ideal anglosajón": Gómez Colomer, Juan Luis, La instrucción del proceso penal por el Ministerio Fiscal: Aspectos estructurales a la luz del Derecho Comparado, en El MISmo, El proceso penal en el Estado de Derecho. Diez estudios doctrinales (Lima, Palestra Editores, 1999), p. 135. Para los iusprocesalistas que centran el principio acusatorio en la diferenciación entre quien investiga-acusa y quien juzga, ese principio no puede ser llevado a la instrucción, esto es, a todas las fases del proceso penal, porque en dicha fase del proceso aún no se ha interpuesto formalmente la acusación. Por todos, y comentando jurisprudencia constitucional, véase: MARTín PASTOR, José, El Ministerio Fiscal como 
En consecuencia, y sin descartar otros principios o garantías como esenciales o connaturales al principio acusatorio, creemos que su fundamento-fin yace en la necesidad de garantizar al justiciable la imparcialidad del órgano encargado de su enjuiciamiento ${ }^{15}$, garantía que, como alguna doctrina se ha encargado de subrayar, es una "metagarantía" de jerarquía axiológica superior, pues opera como presupuesto necesario y previo para la operatividad práctica de las demás garantías fundamentales. ${ }^{16}$ Esta imparcialidad del Juez, en cualquier fase del proceso en que éste intervenga -investigativa, preliminar o preparatoria, y de juzgamiento-, se ve fomentada por la pasividad que frente a los requerimientos de la Fiscalía le demanda un esquema acusatorio ${ }^{17}$.

Para que la estructura acusatoria se propague también a la etapa de instrucción, es menester entonces que la investigación sea conducida por un

director de la investigación oficial en el proceso penal (Bolonia, Publicaciones del Real Colegio de España, 2005), pp. 362-363, quien sostiene que en caso contrario se establecería en el procedimiento preliminar una "estructura acusatoria”. En ese orden de ideas, Gómez Colomer, Juan Luis, El Ministerio Fiscal ¿Eje de la reforma procesal penal?, en Picó i Junoy, Joan (director), Problemas actuales de la Justicia Penal (Barcelona, Bosch, 2001), pp. 32-33, explica que como se ha entendido el principio acusatorio en la doctrina científica y jurisprudencial española, la instrucción por parte el Juez no es incompatible con el modelo de proceso acusatorio.

${ }^{15}$ Del Río Ferretti, Carlos, Los poderes de decisión del juez penal. Principio acusatorio y determinadas garantías procesales (el deber de correlación) (Santiago, Editorial Jurídica de Chile, 2009), pp. 71 ss.; Horvitz, M.I. - López, Julián, cit. (n. 4), I, p. 44, indican que la distribución de funciones impuesta por aplicación del principio acusatorio es considerada actualmente una garantía individual implícita en el derecho a ser juzgado por un tribunal independiente e imparcial. El Tribunal Constitucional español resolvió en la ya célebre sentencia 145/1988, de 12 de julio, que la acumulación de las funciones instructora y decisora es contraria al derecho al juez legal imparcial como al principio acusatorio, que se encuentra implícito en el derecho constitucional a un "proceso con todas las garantías".

${ }^{16}$ Bovino, Alberto, El Ministerio Público en el proceso de reforma de la justicia penal de América Latina, en El mismo, Problemas del Derecho procesal penal contemporáneo (Buenos Aires, Editores del Puerto, 1998), pp. 31-32. También, Mercedes Alliaud, Alejandra, Principio acusatorio. Estudio histórico-comparado de su génesis y evolución, en HeNDler, Edmundo S. (compilador), Las garantias penales y procesales. Enfoque histórico-comparado (Buenos Aires, Editores del Puerto, 2004), pp. 209 ss. Moreno Catena, Víctor - Cortés Domínguez, Valentín - Gimeno Sendra, V., Introducción al Derecho procesal (2a edición, Madrid, Colex, 1997), p. 256, señalan a la imparcialidad del juzgador como una de las notas características de la función judicial, y tal vez la primera que debe concurrir para que pueda decirse actuada la potestad jurisdiccional.

${ }^{17}$ Una visión crítica respecto a la equiparación que realiza el sistema procesal estadounidense entre imparcialidad y pasividad, así como la utilización del sistema acusatorio como excusa para la pasividad judicial, en PizzI, William, Juicios y mentiras (traducción al castellano de C. Fidalgo Gallardo, Madrid, Tecnos, 2004), pp. 169 y 174. 
tercero, el Ministerio Público, el que requerirá al tribunal la autorización para realizar aquellas diligencias o actuaciones que puedan afectar los derechos del imputado o terceros.

\section{ESQUEMA ACUSATORIO Y OBLIGATORIEDAD DE LA ACCIÓN PENAL}

Como ha sido dicho con razón, la decisión entre configuración acusatoria e inquisitiva del proceso no lleva consigo todavía una decisión sobre si en todos los casos en que hay un hecho punible, la persecución ha de ser obligatoria o si hay que tomar en cuenta también consideraciones de oportunidad, sobre todo el interés público, para abstenerse de ella ${ }^{18}$. En efecto, sea la obligatoriedad o la discrecionalidad el principio que comande la actuación del Ministerio Público en un determinado ordenamiento acusatorio, el juez siempre actuará como un pasivo árbitro que interviene sólo ante y respecto de los requerimientos de las partes ${ }^{19}$.

Sin embargo, la asociación de la discreción de la Fiscalía en la persecución

${ }^{18}$ Goldschmidt, James, Problemas jurídicos y politicos del proceso penal (Barcelona, Bosch, 1935), p. 73; para Aguilera Morales, Encarnación, El principio de consenso. La conformidad en el proceso penal español (Barcelona, Cedecs, 1998), p. 246, al comportar el principio acusatorio sólo la necesidad de que una persona distinta del Tribunal mantenga la acusación para que el juicio oral comience y pueda desarrollarse contradictoriamente, de ello no se infiere la existencia de un derecho subjetivo material de las partes sobre el objeto del proceso penal, ni un poder de disposición respecto de este último; De La Oliva, A. y otros, cit. (n. 9) p. 40, explica que "la correlación principio dispositivo-forma contradictoria no va acompañada por otra entre el principio de oficialidad y la forma inquisitiva. El principio de oficialidad puede combinarse con la forma contradictoria y, de hecho, así sucede en muchos ordenamientos procesales penales, entre los que se cuenta el nuestro [español]"; y, Andrés I., Perfecto, cit., (n. 12), p. 466, concluye que "no existe ninguna razón para postular que la disponibilidad de la pretensión procesal sea una implicación estructural de ese modo de entender el proceso [proceso de partes], y no -como en efecto sucede- una forma degradada del mismo, la que prevalece en los Estados Unidos".

${ }^{19}$ Como nota Clariá, J., cit. (n. 4) I, p. 231, "el proceso no dejará de ser acusatorio aunque se prohíba la disponibilidad de su contenido sustancial o formal de las partes". No creemos que sea así en sentido inverso, pues un sistema inquisitivo haría infecunda la discrecionalidad del fiscal si el juez de todas formas pudiera perseguir y acusar por el hecho desestimado o alterado por aquél. En similar sentido, Maturana Mieuel, Cristián - Montero López, Raúl, Derecho procesal penal (Santiago, LegalPublishing, 2010), II, p. 568; y PizzI, William, Understanding Prosecutorial Discretion in the United States: The Limits of Comparative Criminal Procedure as an Instrument of Reform, en Obio St. Law Journal, 54 (Fall, 1993), p. 1353, para quien es un Juez activo en la formulación de cargos y en el desarrollo de la prueba lo que quebrantaría la tradición adversarial americana. 
penal al sistema acusatorio de justicia ${ }^{20}$ se explica plausiblemente porque aunque la obligatoriedad de la acción penal rija legalmente -incluso a nivel constitucional- como máximo postulado para el desempeño del Ministerio Público, la carencia de controles judiciales sobre el mérito de la omisión de la persecución que supone un "esquema acusatorio" de proceso, dejará suficiente margen para "bolsones de discrecionalidad" en el ejercicio de la acción penal, mediante el expedito subterfugio de enmascararlo con argumentos técnico-jurídicos aparentes e incontrolados. Es esto último lo que justifica

${ }^{20}$ Cfr. Lynch, Gerard E., Prosecution: Prosecutorial Discretion, en Dressler, Joshua (editor), Encyclopedia of Crime \& Justice (2a edición, MacMillan Reference USA, New York, 2002), m III, p. 1246; LANGER, Máximo, From Legal Transplants to Legal Translations: The Globalization of Plea Bargaining and the Americanization Thesis in Criminal Procedure, en Harvard International Law Journal, 45 (invierno de 2004), p. 21; LANGer, Máximo, La dicotomía acusatorio-inquisitivo y la importación de mecanismos procesales de la tradición jurídica anglosajona. Algunas reflexiones a partir del procedimiento abreviado, en HENDLER, Edmundo (compilador), Las garantías penales y procesales. Enfoque histórico-comparado (Buenos Aires, Editores del Puerto, 2004), p. 258, indica que la negociación entre acusador y acusado se ajusta perfectamente al modelo de disputa que él propone -muy próximo al adversarial-, pues si el proceso penal es una disputa entre dos partes, es natural que ellas puedan negociar sobre aquélla, poniéndose total o parcialmente de acuerdo sobre cuál es el objeto de la controversia o sobre si siquiera existe alguna. En el medio nacional Duce, Mauricio y Riego, Cristián, cit. (n. 14), pp. 289 y ss. en relación a la compatibilidad de las salidas alternativas con los modelos acusatorios. FerRAJoli, L., cit. (n. 12), pp. 567 ss., estima que el nexo entre el modelo teórico acusatorio y la discrecionalidad de la acción penal responde sólo a un reducto, del todo injustificado, del carácter originariamente privado y después sólo cívico o popular de la iniciativa penal, que no se justifica al afirmarse el carácter público del derecho penal y sus funciones de prevención general no sólo de las venganzas sino asimismo de los delitos. Por el contrario, asevera este autor que el modelo teórico acusatorio "comporta, lógica y funcionalmente, el principio opuesto de la obligatoriedad y la irrevocabilidad de la acción penal por parte de los acusadores públicos, bien se prevea como exclusiva o, por el contrario, en concurrencia con formas más o menos amplias de acción popular y voluntaria”; ANDRÉs IbÁÑEz, Perfecto, El Ministerio Fiscal entre "viejo" y "nuevo" proceso, en Revista de Ciencias Penales, número especial (1990-1993), pp. 49-50, sostiene que en un sistema acusatorio la acusación se rige en su actuación por el principio de estricta legalidad y el consiguiente de obligatoriedad de la acción, ambos en función de los de igualdad y certeza o seguridad jurídica, profundamente inscritos en la esencia misma del Estado de Derecho. Agrega el autor que la disponibilidad de la acusación y la posibilidad de la negociación sobre el objeto del proceso característico del proceso en los Estados Unidos hace imposible la vigencia del proceso acusatorio, al entrar en colisión frontal con las exigencias de jurisdicción. Niega también este nexo, Armenta Deu, T., Principio, cit. (n. 9), p. 37; y La misma, Criminalidad de bagatela y principio de oportunidad: Alemania y España (Barcelona, PPU, 1991), p. 187. 
con toda razón que algunos autores estimen "esencial” el control del juez al concepto mismo de obligatoriedad de la acción penal ${ }^{21}$.

${ }^{21}$ Cfr. ZAGrebelsky, Vladimir, Independencia del ministerio público y obligatoriedad de la acción penal, en Revista de Ciencias Penales, número especial (1990-1993), p. 112; Delmas-Marty, M., cit. (n. 14), pp. 453-454, expresa que la obligación de perseguir penalmente tiene como corolario necesario el establecimiento de un instrumento de control que impida al Ministerio Fiscal sustraerse de él; OrTells Ramos, M., Cuatro, cit. (n. 14), p. 314, expone que cualquiera sea el régimen de la potestad de acusar, reglada o discrecional, para garantizar que las decisiones sobre su ejercicio sean ajustadas a derecho, es necesario que se prevea una posibilidad de examen judicial de tales decisiones, lo cual, por otra parte, sería coherente con el control judicial general y pleno de los actos del Poder Ejecutivo y asimilados en un Estado de Derecho; RodríGUEZ GARCía, Nicolás, El consenso en el proceso penal español (Barcelona, JMB, 1997), p. 165, precisa que "el que se reconozca que el Fiscal sea el que tiene que negociar con la defensa no supone que se tenga que excluir la necesidad de llevar a cabo un control judicial de la actividad desarrollada por éste”; Del Río, C., Proceso penal, cit. (n. 2), p. 126, explica que "una verdadera preocupación por la restricción de la discrecionalidad penal supone imponer o reforzar la eficacia normativa de la ley penal, a través del sometimiento a ella no sólo del juez, sino también del órgano de la acusación penal pública, y con el debido control jurisdiccional de dicho sometimiento. De lo contrario la legalidad penal es puro espejismo"; el Tribunal Constitucional italiano, en sent. no 88/91, citada por Delmas-MARTy, M., cit. (n. 14), pp. 454-455, recuerda la importancia del control del juez para prevenir la eventual inacción y las lagunas en las investigaciones y evitar que sus opciones en esta materia se traduzcan en un ejercicio (o no ejercicio) discriminatorio de la acción penal. A mayor abundamiento, bien es verdad que en el sistema de justicia criminal estadounidense, la amplia discreción del fiscal en el ejercicio de la acción penal hunde sus raíces en razones de corte histórico -herencia de la tradición inglesa de la "private prosecution"-, así como a su tradición política -ser el fiscal elegido popularmente en la mayoría de los estados, lo que permite un control local de las políticas criminales de persecución-, cfr. Bovino, Alberto, La persecución penal pública en el derecho anglosajón, en Revista Latinoamericana de Politica Criminal, 2 (1997), pp. 35-79, no puede desconocerse que en último término, hoy en día dicha discrecionalidad pervive al alero de la jurisprudencia constante de su Corte Suprema, la que ha desestimado la posibilidad de forzar al Fiscal a acusar contra su voluntad, fundándose principalmente en la doctrina de separación de poderes, en detalle sobre este asunto, véase: Goldstein, Abraham S., The Passive Judiciary. Prosecutorial Discretion and the Guilty Plea (s.l., Louisiana State University Press, 1981), pp. 53 ss. Un examen de esta jurisprudencia también en Cabezudo Rodríguez, Nicolás, El Ministerio Público y la justicia negociada en los Estados Unidos de Norteamérica (Granada, Comares, 1996), pp. 29 ss. Gershman, Bennett L., The Prosecutor as a "Minister of Justice”, en N.Y.St.B.J., 60 (1988), p. 64, concluye así que la falta de control constituye una tentación demasiado fuerte para algunos Fiscales de cruzar la línea que separa el comportamiento ético del que no lo es, sobretodo cuando por medio de esta actitud se facilita ciertos intereses personales, como el objetivo de ganar casos. Desde un enfoque más general, Fernández González, Miguel Ángel, El derecho constitucional al debido proceso con especial aplicación al nuevo proceso penal, en Anales de la Facultad de Derecho. 
En los sistemas de justicia penal de estructura inquisitiva, el interés público o social en la persecución penal se resguarda con los principios de obligatoriedad de la acción penal y de investigación o instrucción -o como algunos los llaman, de investigación integral o instrucción plena-, principio este último con arreglo al cual el Tribunal debe investigar la verdad material y no conformarse con lo que el Ministerio Público y el imputado someten a su consideración, le exponen y solicitan. Por consiguiente, el juez penal no se conforma con la llamada verdad formal, y la ley no confía respecto de una consecuencia jurídica tan importante como la pena, en el criterio de quienes participan en el proceso y en lo que tienen a bien exponer al Tribunal ${ }^{22}$. Esta corresponsabilidad sobre la persecución penal que para el juez arrastra el principio de investigación, en sinergia con los principios de oficialidad y de impulso oficial -por los cuales la persecución penal es promovida de oficio por órganos del $\mathrm{Estado}^{23}$ - permite garantizar en gran medida la vigencia del

Universidad de Chile, 2 (2005), pp. 78-79, afirma que lo resuelto por los órganos que ejercen jurisdicción, pero que no juzgan como el Poder Judicial, pueden siempre ser revisadas por este último, cuando el órgano jurisdiccional no integra dicho Poder del Estado. Agrega este autor que "cuando se prohíbe impugnar lo resuelto por un órgano jurisdiccional ante los tribunales o, existiendo recursos, estos son insuficientes para dar cabal protección a la defensa de los derechos, lo que en realidad se está haciendo es atribuir a aquel órgano el ejercicio de la función judicial, cuyo núcleo es el juzgamiento, vulnerando lo preceptuado en el artículo 73 CPol. Más aún, desde el punto de vista de los derechos fundamentales, en ese caso se da una de las hipótesis de la conducta prohibida por el artículo $19 \mathrm{~N}^{\circ} 3$ inciso $4^{\circ}$, ya que el órgano jurisdiccional se ha erigido en comisión especial, esto es, una persona o grupo de personas que, sin ser un tribunal establecido por la ley, ejercen la función judicial".

${ }^{22}$ Baumann, Jürgen, Derecho procesal penal. Conceptos fundamentales y principios procesales (traducción castellana de C. A. Finzi, Buenos Aires, Depalma, 1986), pp. 7576. Agrega este autor que los principios de instrucción y el inquisitivo significan, de por sí, lo mismo: el Tribunal debe investigar, y no solamente decidir acerca de lo que le ha sido expuesto. También ClaRIÁ, J., cit. (n. 4), p. 237, para quien este principio es el que sustenta más enérgicamente el rasgo inquisitivo del proceso. En similar sentido, KüHne, Hans-Heiner, "Germany”, en Van Den Wyngaert, Christine (editora), Criminal Procedure Systems in the European Community (Londo y otras, Butterworths, 1993), p. 145; y Roxin, C., Derecho procesal, cit. (n. 4), pp. 99 ss.

${ }^{23}$ Baumann, J., cit. (n. 22), pp. 42 y 105; y Horvitz, M. I. y López, J., cit. (n. 4) I, pp. 36 ss. Sobre el principio oficial en el proceso penal alemán, véase: Gómez CoLOMER, Juan Luis, El proceso penal alemán. Introducción y normas básicas (Barcelona, Bosch, 1985), p. 46. Para Clariá, J., cit. (n. 4), p. 234, del principio de oficialidad deriva la obligatoriedad, y de ésta derivan a su vez las reglas de oficiosidad y legalidad, desdoblándose esta última en las de promoción necesaria e irrefragabilidad. Creemos, al igual que Cerda, Rodrigo y Hermosilla, Francisco, cit. (n. 4), p. 190, que "no debe confundirse el principio de legalidad [que nosotros preferimos llamar principio de obligatoriedad de la acción penal] con el de oficialidad, pues este último se refiere a la idea 
principio de obligatoriedad de la acción penal y el interés público que éste ampara, esto es, que el Ministerio Público persiga todos los delitos de acción pública de que tome conocimiento. En otras palabras, la tarea de todos los órganos estatales que intervienen en el procedimiento está presidida por las mismas reglas, de modo que la actividad oficiosa del tribunal contribuye a la eficiencia estatal en la coerción penal, en la medida que el Ministerio Público desempeñe errónea o displicentemente su labor de persecución ${ }^{24}$.

Empero, en los sistemas acusatorios, precisamente a fin de configurar y preservar su carácter de tal en resguardo en último término de la imparcialidad del juzgador, el legislador promueve el interés colectivo en la persecución criminal sólo gravando al acusador público con la instrucción y acusación obligatoria respecto de los hechos delictivos, y liberando a los Tribunales de los gravámenes procesales que le significan el principio de instrucción, aun a riesgo que esta escisión mengüe la efectiva actualización del interés público en la persecución penal ${ }^{25}$. $\mathrm{Al}$ respecto se ha dicho que "la decisión que favorece al principio ne procedat iudex ex officio importa, en verdad, debilitar el principio de legalidad por intermedio de la destrucción de su control jurisdiccional previo, de modo tal que implica el más amplio reconocimiento político posible del principio de oportunidad para la fiscalía, en cuya órbita interna se desarrolla, únicamente, ese control, con valor decisivo en el procedimiento" ${ }^{26}$. En efecto, mientras un ordenamiento

de persecución penal pública de los delitos, de oficio, sin consideración de la voluntad del ofendido ni de ninguna otra persona. El principio de oficialidad está asociado a la idea de monopolio estatal en el ejercicio de la acción penal y su antítesis teórica es el principio dispositivo".

${ }^{24}$ Como señala Cafferata, J., El proceso penal, cit. (n. 4), p. 12, respecto de los códigos procesales mixtos argentinos, en ellos "el triunfo de la verdad" es el objetivo supremo del proceso, al que deben contribuir, respetando ciertas reglas, pero sin distinción sustancial de roles, todos los órganos públicos intervinientes, esforzándose vanamente en disimular la innegable contraposición de intereses diferentes, ínsita en cualquier proceso, bajo el eufemismo de un común interés de "justicia”.

${ }^{25}$ Para Bovino, Alberto, Proceso penal y derechos humanos: la reforma de la administración de la justicia penal, ahora en EL MISMO, Problemas del Derecho procesal penal contemporáneo (Buenos Aires, Editores del Puerto, 1998), p. 19, la existencia del interés público en la persecución de los hechos punibles, en términos generales, no justifica las facultades inquisitivas reconocidas a los Jueces -como las inherentes al principio de instrucción-, ya que ese interés público no quita el carácter interesado de la persecución penal y se opone al interés del propio imputado en resistir la persecución, todo lo que impediría al Juez actuar como representante del interés persecutorio y al mismo tiempo, controlar su propia actuación y, también, el eventual conflicto que surge entre los diversos intereses que se manifiestan en el procedimiento penal.

${ }^{26}$ Maier, Julio B. J., Derecho procesal penal. Parte general. Sujetos procesales (Buenos Aires, Editores del Puerto, 2003), II, p. 371. 
permita al Tribunal forzar al Ministerio Público a formular acusación ante la existencia de antecedentes bastantes, decretar en el juicio las diligencias investigativas necesarias para acreditar el delito o la participación, o dirigir el interrogatorio de los testigos, como institutos tributarios del principio de investigación, la persecución obligatoria que la ley impone al Ministerio Público se ve reforzada o asegurada, por la actuación del Tribunal, aun cuando ello suponga desmejorar lo acusatorio del proceso ${ }^{27}$. Mas, cuando se resta a un sistema penal del principio de investigación, así como de las concretas técnicas judiciales a través de las que se realiza, y se adhiere al principio de aportación de parte ${ }^{28}$ como ocurre en las estructuras acusatorias de proceso, el principio de obligatoriedad de la acción penal ve encogida su situación para alcanzar verdadero protagonismo, lo que comporta el peligro de hacer de aquél una simple fachada ante el correlativo incremento de los espacios de discrecionalidad de la acción penal para el órgano persecutor.

La correcta verificación o establecimiento de los hechos relevantes para la resolución del asunto penal, como presupuesto de la aplicación del derecho objetivo al caso concreto que persigue el proceso, y de la posibilidad de arribar a una decisión justa, se verá normalmente entorpecida en el procedimiento que no dota a la jurisdicción de los mecanismos adecuados para tal verificación o establecimiento ${ }^{29}$. Estos mecanismos, que garantizan la maximización

${ }^{27}$ Para Asencio Mellado, José María, Principio acusatorio y derecho de defensa en el proceso penal (Madrid, Trivium, 1991), p. 41, las características que se pueden asignar al objeto procesal penal surgen necesariamente y se vinculan de forma muy directa al principio de necesidad, a la indisponibilidad en su conformación por las partes, y al también principio de búsqueda de la verdad material en lo tocante a su total integración por el órgano jurisdiccional. Convergiendo estos tres principios, "una vez el hecho sometido a la consideración del órgano judicial y aunque tal traslación lo sea simplemente parcial o fraccionada, éste queda en poder del Juez o Tribunal el cual tiene el deber de apreciarlo en toda su integridad y agotarlo en la totalidad de sus vertientes".

${ }^{28}$ Conforme a este principio, la carga de la prueba y la iniciativa de los actos de producción de prueba recaen en las partes, sin que se reconozca al tribunal facultades para intervenir en ella. El principio de aportación de parte descansa, fundamentalmente, en la autonomía de la voluntad particular y, por ello, determina que el tribunal no se interese por la averiguación autónoma de la verdad, cfr. MonTERo, Juan y otros, Derecho jurisdiccional. Parte general, cit. (n. 4), p. 505; y Horvitz, M. I. - López, J., cit. (n. 4), I, p. 41.

${ }^{29}$ Destacan la necesidad de dotar a la jurisdicción de los mecanismos adecuados para la correcta verificación o establecimiento de los hechos relevantes del caso, entre otros, Ferrajoli, L., cit. (n. 12), pp. 36 ss.; Schünemann, Bernd, ¿Crisis del procedimiento penal? (¿marcha triunfal del procedimiento penal americano en el mundo?), ahora en El mismo, Temas actuales y permanentes del Derecho penal después del milenio (Madrid, Tecnos, 2002), pp. 296-297, en relación al deber judicial de esclarecimiento que se ve frustrado en un "guilty plea" negociado; y en el espectro nacional, véase: DEL 
de la búsqueda de la verdad, ya menguados en todo proceso $^{30}$, se ven especialmente deprimidos en el acusatorio, pues en éste la pasividad del Juez se erige como otra regla no epistemológica o contra-epistemológica ${ }^{31}$, orientada a tutelar otros bienes, derechos, intereses o fines prácticos concurrentes, entre los que nos interesa la imparcialidad del órgano jurisdiccional, y que reducen el número de agentes públicos que actúan positiva y proactivamente para establecer la verdad, fiscal y juez, concentrando dicha actividad en el primero.

Finalmente, prevengamos que no ahondaremos en esta investigación sobre si la estructura acusatoria del proceso colisiona o no con el principio de verdad material o sustantiva, pues la complejidad del asunto merece un estudio extenso y particularizado que supera los márgenes de este artículo, contentándonos por ahora en evidenciar que, en su caso, y a fin de no perma-

Río Ferretti, Carlos, Dos formas discutibles de poner en duda el carácter cognoscitivo de la aplicación judicial del derecho penal: El principio del consenso y la garantía de la no agravación punitiva, en Revista de Derecho de la Pontifica Universidad Católica de Valparaíso, 34 (2010), p. 352.

${ }^{30}$ Gascón Abellán, María, Los hechos en el Derecho. Bases argumentales de la prueba ( $3^{\text {a }}$ edición Madrid, Marcial Pons, 2010), pp. 116-117, expone que con la institucionalización del proceso se incorporan importantes excepciones a la regla epistemológica del modelo cognoscitivista que establece que, "cualquier elemento que permita aportar información relevante sobre los hechos que se juzgan debe poder usarse”, y así se mencionan entre dichas limitaciones, a las restricciones a los medios de prueba admisibles, la prohibición de probar ciertos hechos más que con determinados medios de prueba prefijados por la ley, limitar el uso de pruebas ya adquiridas o prohibir directamente la adquisición y subsiguiente uso de ciertas pruebas, etc. FERRER BELTRÁn, Jordi, La valoración racional de la prueba (Madrid, Marcial Pons, 2007), pp. 35-36, profundiza en esta idea, al explicarnos que la decisión que debe adoptar el juez o tribunal acerca de los hechos probados no es enteramente libre, sometiéndola a una serie de reglas que regulan tanto la decisión final, en algunos casos, como el proceso por el que puede llegar a esa decisión. Identifica fundamentalmente tres tipos de reglas sobre la prueba, en función del objeto sobre el que versan: $i$ ) reglas sobre la actividad probatoria; ii) reglas sobre los medios de prueba; y iii) reglas sobre el resultado probatorio. Sobre las primeras -aquí atingentes-incluyen reglas que establecen el momento en que se inicia la fase de prueba y en el que finaliza, los momentos procesales en que pueden o deben proponerse las pruebas para su admisión, los sujetos a quien corresponde realizar esa proposición, etc. Agrega el autor que estas reglas pueden ser entendidas como excepciones impuestas por el derecho a los principios generales de la prueba, pues estos principios, no específicamente jurídicos, impondrían por ejemplo, la admisión y la práctica de toda prueba que pueda aportar algún elemento de juicio, aunque su peso sea mínimo.

${ }^{31}$ Así llama Del Río, C., Dos formas, cit. (n. 29), p. 356, al principio de consenso y a la garantía de no agravación punitiva, que creemos no son sino algunas de las tantas consecuencias que la pasividad del órgano jurisdiccional o su ajenidad al conflicto y a las partes, implícitas en los sistemas acusatorios. 
necer en un plano puramente teórico, "la obtención de una verdad material o formal a través de un proceso judicial, no es más que la consecuencia de que en dicho proceso predomine el principio de investigación por sobre el de aportación de parte o viceversa, trasunto, a su vez, del par dialéctico formado por los principios inquisitivo y acusatorio (...) Por consiguiente, cuando un determinado procedimiento o fase procesal esté presidida por el principio acusatorio lo estará también por el de 'aportación' y, si el inquisitivo es el dominante, estará informada por el de 'investigación"”32.

${ }^{32}$ De Diego Díez, Luis Alfredo, La conformidad del acusado (Valencia, Tirant lo Blanch, 1997), pp. 434-435. En el mismo sentido: FerRajoli, L., cit. (n. 12), p. 45, razona que la verdad formal es más reducida en cuanto al contenido informativo que cualquier hipotética verdad sustancial, entre otros factores, porque se circunscribe a las tesis acusatorias formuladas conforme a las leyes. MAIER, J., Derecho procesal penal, cit. (n. 26), p. 447, es clarificador al señalar que "no debe confundirse la afirmación del aforismo "veritas non auctoritas facit iudicium" tampoco en otro sentido, si se quiere, de carácter formal: él no explica la necesidad de que los tribunales sean convertidos, con sacrificio de su necesaria imparcialidad, en investigadores de la verdad, aun de oficio, mediante reglas procesales que pululan en los enjuiciamientos penales de cuño europeo-continental; se trata, antes bien, de que ellos apliquen la coacción penal estatal sobre la base ineludible del conocimiento de la verdad y prescindan de aplicarla cuando carezcan de ese conocimiento (in dubio pro reo)". Por otra parte, la misma construcción conceptual de dos verdades -material y formal- ya nos resulta un tanto contrahecha y engañosa, si tenemos en cuenta lo sostenido por MAIER, J., Derecho procesal penal argentino, cit. (n. 4), pp. 562 ss., quien elucida que el concepto de verdad no admite la distinción conceptual entre verdad real o material, adjudicada al proceso penal como ideal, y la verdad formal, adjudicada al proceso civil, pues una y otra rama del derecho utilizan el mismo concepto. A la contraposición verdad real - verdad formal no se arribó por una discordancia conceptual, acerca de lo que es o significa la verdad, sino, antes bien, por contraposición entre formas jurídicas distintas del procedimiento judicial, gobernadas por principios diferentes. En el procedimiento penal, el Juez inquiere, para averiguar la verdad, por sí mismo, en las oportunidades que la ley le prefija y con los poderes específicos que la misma ley establece, regla cuyo fundamento político reside, precisamente, en la naturaleza pública de la pena estatal, a diferencia del proceso civil, cuyo principio superior reside en la autonomía de la voluntad particular, por lo que el Juez civil representa por principio, el papel de un árbitro imparcial, que carece de poderes propios de instrucción; por ello él, por regla general, no se interesa por la averiguación por sí -autónoma- de la verdad acerca del objeto a conocer, para resguardo de su imparcialidad frente a intereses privados y como emanación de la naturaleza propia de los intereses en juego (esencialmente disponibles). Hacia el mismo punto va DAMASKA, Mirjan R., Evidence Law Adrift (New Haven-London, Yale University Press, 1997), pp. 110 ss., al explicar que los sistemas de justicia continentales entienden que sus procesos penales -a diferencia de los civiles- sirven para la realización de la política estatal hacia el crimen. Este objetivo debe ser perseguido para la protección del orden público, incluso en la ausencia de una actual disputa entre el ofensor y el Estado, y esta necesidad de establecer el predicado fáctico para la realización de la política penal -la 


\section{Sistema PRocesal PENAL ACUSATORIo CHILENo}

No obstante que en gran parte nuestra doctrina, en la línea de la tradición jurídica continental ya apuntada, continúa encapsulando los rasgos definitorios de lo acusatorio en torno a la separación de las funciones de acusar y juzgar, la exigencia de acusación previa al juicio, y la división del proceso en

separación del culpable del inocente, por ejemplo- induce a remover, o reducir, al menos aquellos impedimentos para la obtención de la verdad en los procesos de resolución de disputa que derivan de un control de las partes sobre los parámetros y existencia de la controversia. En el sistema de justicia angloamericano, en cambio, el penetrante arraigo del control de las partes sobre el establecimiento de los hechos está relacionado a una distintiva misión del proceso legal, como método de resolución de conflicto, sean asuntos civiles o penales. En el caso de estos últimos, ello no excluye de toda consideración la correcta implementación de políticas criminales, pero es un objetivo subordinado o secundario. TARUfFo, Michele, La prueba de los hechos (traducción castellana de J. Ferrer Beltrán, Madrid, Trotta, 2002), pp. 24 ss., rechaza la distinción entre una verdad formal (o judicial o procesal) que sería establecida por media de las pruebas y los procedimientos probatorios, y por otro lado, una verdad material (o histórica, empírica o, simplemente verdad) referida al mundo de los fenómenos reales o, en todo caso, a sectores de experiencia distintos del proceso y que se obtendría mediante instrumentos cognoscitivos distintos de las pruebas judiciales; igualmente desestima este autor la distinción entre una verdad relativa, típica del proceso, y una verdad absoluta, que existiría en algún lugar fuera del proceso. CARnELUTTI, Francesco, La prueba civil (traducción castellana de N. Alcalá-Zamora y Castillo, Buenos Aires, Arayú, 1955), pp. 20-21 y 25, enseña que la distinción entre verdad material o verdad verdadera y verdad formal o jurídica, no es más que una metáfora, pues, "en substancia, es bien fácil observar que la verdad no puede ser más que una, de tal modo que, o la verdad formal o jurídica coincide con la verdad material, y no es más que verdad, o discrepa de ella, y no es sino una no verdad, de tal modo que, sin metáfora, el proceso de búsqueda sometido a normas jurídicas que constriñen y deforman su pureza lógica, no puede en realidad ser considerado como un medio para el conocimiento de la verdad de los hechos, sino para una fijación o determinación de los propios hechos, que puede coincidir o no con la verdad de los mismos y que permanece por completo independiente de ellos". Insiste luego en esta idea al señalar que "basta un límite mínimo a la libertad de búsqueda del juez, para que el proceso de búsqueda de la realidad degenere en proceso formal de fijación; en otros términos: la medida del límite es indiferente para la naturaleza del proceso. La verdad es como el agua: o es pura, o no es verdad. Cuando la búsqueda de la verdad material está limitada de tal modo que ésta no pueda ser conocida en todo caso y con cualquier medio, el resultado, sea más o menos riguroso el límite, es siempre el de que no se trata ya de una búsqueda de la verdad material, sino de un proceso de fijación formal de los hechos". BetTiol, Giuseppe, cit. (n. 12), p. 248, a su turno, estima injusto hacer de la contraposición de la verdad legal y sustancial, que conciernen al proceso civil y penal, respectivamente, un principio absoluto, pues ambos procesos son instrumentos de verdad. 
dos fases que se atribuyen a órganos jurisdiccionales distintos ${ }^{33}$, y aun cuando nuestro CPP. se vió notoriamente influenciado por la Ordenanza Procesal Penal alemana (StPO) de 1877 y por la Ley de Enjuiciamiento Criminal española de 1882, y por textos más modernos como el Código Procesal Penal Modelo para Iberoamérica de 1988 -reconocidamente tributario de la StPO ya mencionada- y el Código Procesal Penal italiano de 1989, lo cierto es que el Proyecto de CPP. chileno presentado por el Ejecutivo al Parlamento, siguió caminos y derroteros que lo distanciaron de manera patente de dichos textos -lo que se incrementa paulatinamente durante su discusión legislativa-, superando gracias a una reestructuración de la orgánica procesal, diversos resabios instruccionistas aún enquistados en diversas instancias de sus procedimientos, y avanzando con holgura hacia una estructura procesal netamente acusatoria ${ }^{34}$.

${ }^{33}$ Cfr. Horvitz Lennon, María Inés, Algunas formas de acuerdo o negociación en el proceso penal: tendencias del derecho comparado, en Revista Ciencias Penales, 40 (1994) 2, p. 29, quien reserva los principios de oralidad, publicidad, inmediación y contradicción para la fase principal o de juicio en sentido estricto; HoRVITZ, M. I. LópeZ, J., cit. (n. 4), I, p. 43, explican que en su núcleo básico, el principio acusatorio impone una distribución de los poderes que se despliegan en la etapa del juicio, impidiendo que quien acusa y juzga sean una misma persona; Maturana, C. - Montero, R., cit. (n. 19), I, pp. 91 ss., pese a lo reciente de su obra, mantienen una caracterización de corte histórico de los sistemas acusatorio, inquisitivo, y mixto, al igual que CASTRO VARGas, Carlos, Resabios inquisitivos en el proceso penal chileno (Santiago, Metropolitana, 2010), pp. 49 ss.

${ }^{34} \mathrm{Cfr}$. Tavolari, Raúl, Instituciones del nuevo proceso penal. Cuestiones y casos (Santiago, Editorial Jurídica de Chile, 2005), pp. 268, en cuyo juicio, el sistema procedimental introducido por el conjunto de cuerpos legales que se denomina la Reforma Procesal Penal, consagra un régimen de juzgamiento y decisión de los conflictos penales que la dogmática procesal penal y el Derecho comparado, denominan "adversarial”, el que se caracteriza por generar un marco igualitario de deberes y derechos para los litigantes del proceso penal, frente a un tribunal al que no se otorgan facultades de impuso ni iniciativa probatoria; Duce, M. - Riego, C., cit. (n. 14), p. 36, indican que en el contexto del proceso de reforma procesal penal vivido en Latinoamérica, podríamos hablar de un "sistema acusatorio moderno", caracterizado por la existencia de un juicio oral, público y contradictorio como etapa central del procedimiento; la separación de funciones jurisdiccionales y persecutorias y, consiguientemente, la diferenciación de los roles entre jueces y fiscales (en este modelo la dirección de la investigación no es jurisdiccional y, por tanto, se entrega a los fiscales); y el reconocimiento de los derechos básicos del debido proceso a favor de los imputados; Chahuán Sarrás, Sabas, Manual del nuevo procedimiento penal ( $3^{a}$ edición, Santiago, LexisNexis, 2007), pp. 9-10, identifica al "sistema acusatorio-contradictorio" con formas democráticas de gobierno en las que hay una efectiva vigencia de un estado de derecho, y que cuenta con las siguientes características: instancia única en relación con la sentencia definitiva, acusación confiada al Ministerio Público, igualdad de partes, pasividad e imparcialidad del juez, libertad en 
Claramente para nuestro legislador lo acusatorio no se contenta con atribuir las funciones requirentes y decisorias respecto al objeto principal del proceso a organismos distintos, y extiende esta dualidad también a la etapas preliminares de control de la instrucción y preparación del juicio, es decir, amplía la "terciedad" o "ajenidad" del juez o el principio acusatorio para su pronunciamiento sobre el hecho punible y la pretensión procesal a todo asunto o incidente relevante en que se enfrenten intereses contrarios

la apreciación de las pruebas rendidas, oralidad del juicio, publicidad de las actuaciones procesales, y contradictorio. Explica que no basta a un sistema procesal penal correspondiente a una república democrática un sistema formalmente acusatorio, sino que debe tratarse de un sistema "acusatorio adversarial", con efectivo antagonismo de dos posiciones, de lo contrario cualquier sistema podría caracterizarse como acusatorio si la formulación de la acusación, aunque sea un mero formulismo por escrito, se entrega a un juez diverso; Bofill Genzsch, Jorge, El juicio oral. Preparación y desarrollo, en AA.VV., El nuevo proceso penal chileno (Concepción, Universidad de Concepción, Facultad de Ciencias Jurídicas y Sociales, Departramento de Derecho Procesal, 2000), p. 201, asevera que lo acusatorio es mucho más que entregar la facultad de acusar a un sujeto u órgano diferente de aquél que tiene que emitir el juzgamiento, pues, de lo contrario, se podría calificar la versión original de nuestro Código de Procedimiento Penal como semi-acusatoria, habida cuenta de la existencia, a la sazón de los promotores fiscales, sobre quienes recaía la función de examinar los antecedentes del sumario y formular la acusación; Salas Astrain, Jaime, Problemas del proceso penal (Santiago, Librotecnia, 2009), p. 25, indica que "el Juez de Garantía, con el actual proceso penal se vino a equiparar su función con la desplegada históricamente por otras judicaturas, en especial por la civil, en cuanto a que al habérsele relevado de su calidad de parte, debe limitarse ahora sólo a emitir un pronunciamiento respecto de la procedencia o no de la petición o de la pretensión penal formulada por el persecutor penal, según sea el caso"; NúÑEZ, J. C., cit. (n. 4), II, p. 22, concluye que el CPP. consagra un "típico sistema acusatorio de naturaleza adversarial que, en base a los supuestos de la indefectibilidad, del juez natural, de la imparcialidad, del non bis in idem, de la presunción de inocencia del imputado, del derecho de defensa, de la protección de la víctima, de la cautela de garantías, de la libertad de pruebas y de la instancia única, se rige, entre otros, por los principios de la oportunidad, de la disponibilidad, de la concentración, de la oralidad, de la inmediación, de la publicidad y de la contradictoriedad"; Maturana, C. - MonTERO, R., cit. (n. 19), I, p. 100, conservadoramente centran su caracterización del sistema recogido por el CPP. como acusatorio, por separar las funciones de acusación, defensa y juzgamiento, aun cuando resaltan como propio del principio acusatorio la separación de las funciones de investigación, defensa y decisión que se aprecia durante la fase de investigación y etapa intermedia, ibíd. p. 108; GANDUlFo, E., cit. (n. 14), p. 419, explica que en virtud del "principio acusatorio" el CPP. se presenta en el proceso penal una doble separación: entre el fiscal y el juez, y entre los jueces de la instrucción, del juicio oral y los de ejecución de la pena. CAstro, C., cit. (n. 33), p. 330, quien en vista de los diversos resabios inquisitivos que advierte en el CPP., concluye que "el nuevo sistema chileno no es acusatorio". 
por la Fiscalía y el imputado y su defensa ${ }^{35}$. Complementariamente, el principio de aportación de parte no gobierna tampoco sólo el juicio oral ${ }^{36}$, sino la resolución de todo incidente en las etapas previas, de manera que la extensión de los principios acusatorio y de aportación de parte a todo el proceso penal, conllevan por ejemplo, que la petición de una medida cautelar así como los antecedentes que avalen ésta, deben emanar del Ministerio Público -o la víctima o querellante-, y no puede su discusión ni menos su prueba, originarse o impulsarse por el Tribunal ${ }^{37}$.

Ya en los trabajos preparatorios para la reforma de nuestro procedimiento penal, se destacaba que "la imparcialidad debe abarcar todas las diversas dimensiones que conforman el proceso penal; por ello, se extiende no sólo a la resolución del caso sometido al conocimiento del tribunal, sino que abarca también toda sentencia interlocutoria y todos los actos del procedimiento" ${ }^{38}$. Precisamente para permitir que la estructura acusatoria se comparta sustancialmente en la etapa de instrucción, es que fue indispensable crear el Minis-

${ }^{35}$ Repárese que en el Proyecto de Ley orgánica constitucional del Ministerio Público (Mensaje 160-325) de 5 de noviembre de 1992, en Revista de Ciencias Penales, 40 (1990-1993), pp. 151-173, se proponía el modelo de juez instructor y Ministerio Público acusador, v. Proyecto de Ley Orgánica Constitucional del Ministerio Público, es decir, restableciendo las funciones del Ministerio Público en primera instancia de modo muy similar a las que ejercieron los promotores fiscales hasta 1927. Para proposiciones de reinsertar los promotores fiscales al antiguo sistema inquisitivo véase: RIVADENEIRA, Ricardo, El Ministerio Público y su contribución a la capacidad de investigación del sistema procesal penal, en AA. VV., El Ministerio Público para una nueva justicia criminal (Santiago, Fundación Paz Ciudadana - Escuela de Derecho Universidad Diego Portales - Corporación de Promoción Universitaria, 1994), pp. 127-134. Surge entonces un debate en torno a la necesidad de producir una reforma más global del sistema de justicia criminal, coherente con los procesos radicales que se estaban experimentando en todo el continente, cfr. Horvitz, M. I. - López, J., cit. (n. 4), I, p. 20.

${ }^{36}$ Reconociendo la penetración del principio de "aportación de parte" propio del sistema acusatorio puro o adversarial de origen angloamericano en el CPP. chileno, Del Río, C., Lospoderes, cit. (n. 15), pp. 81-82.

${ }^{37}$ Horvitz, M. I. - López, J., cit. (n. 4), I, p. 42, apuntan que, entendido el principio de investigación oficial como un principio dirigido hacia la actividad del Tribunal, "uno de los rasgos característicos del proceso penal chileno de la reforma es la absoluta pasividad del juzgador, tanto durante la etapa de investigación como durante el juicio oral, lo que implica que éste tiene generalmente vedado la realización de actos de investigación e, incluso, la intervención en la producción de la prueba".

${ }^{38}$ Barros, Luis - Frühling, Hugo - García, Gonzalo - Quintana, Augusto - SÁnchez, Domingo, El proceso penal chileno y su protección de los derechos del imputado, en Proceso penal y derechos fundamentales (Santiago, Corporación Nacional de Reparación y Reconciliación, Colección Estudios, 1994), I, p. 71. Se sigue en esto a Gómez, E.- Herce, V., cit. (n. 4), p. 50, al estudiar las institución de la recusación en el derecho español. 
terio Público, a fin de dejar al juez de garantía como imparcial supervisor de la legalidad de sus actuaciones y requerimientos, y correlativamente, despojar al órgano jurisdiccional del "autocontrol" 39 propio de la etapa sumarial del anterior procedimiento penal, en el cual éste "controlaba y autorizaba" su propia actividad investigativa que pudiera afectar los derechos individuales del imputado o terceros ${ }^{40}$.

${ }^{39}$ El principio de "no autocontrol" es un componente del Estado de Derecho moderno, y según el cual, la función de control siempre debe estar en manos distintas de quien posee la toma de decisiones, cfr. Duce, M. - Riego, C., cit. (n. 14), p. 115; RusCONI, Maximiliano A., División de poderes en el proceso penal e investigación a cargo del ministerio público, en AA. VV, El Ministerio Público en el proceso penal (Buenos Aires. Ad Hoc, 2000), pp. 104-106; y ChAHUÁN, S., cit. (n. 34), p. 20, anota la improbabilidad de este autocontrol por el juez del crimen del CdPP de 1906.

${ }^{40}$ Bofill Genzsch, J., Alcance de la obligación del fiscal de registrar sus actuaciones durante la investigación. Consecuencias de su incumplimiento en las diferentes etapas del procedimiento, en Revista de Estudios de la Justicia, 6 (2005), p. 48; Soto Piñeiro, Miguel, Ministerio Público y política criminal, en AA. VV., El Ministerio Público para una nueva justicia criminal (Santiago, Fundación Paz Ciudadana - Escuela de Derecho, Universidad Diego Portales - Corporación de Promoción Universitaria, 1994), pp. 148-149, indica que de este modo se quita al Tribunal el "lastre imposible de sobrellevar que conlleva la obligación de vigilarse y limitarse a sí mismo, puede recuperar la función que le es propia; la función de Juez, que vigila, controla la regularidad del proceso de instrucción, asegurando durante el mismo la salvaguarda de los derechos fundamentales y libertades públicas de todos los involucrados"; Barros, cit. (n. 38), p. 75 , resaltaba en los estudios preliminares al CPP. que la real vigencia de la garantía de imparcialidad del tribunal exige que tanto la instrucción como el juicio sean realizados por diferentes personas, y de ahí la necesidad de entregar la preparación y planteamiento de la acusación al Ministerio Público; Bustos Ramírez, Juan y otros, El proceso penal chileno, en Proceso penal y derechos fundamentales (Santiago, Corporación Nacional de Reparación y Reconciliación, Colección Estudios, 1994), 1, p. 363, también destaca en los trabajos preparatorios que, "el modelo que mejor vela por el respeto de los derechos de los imputados durante la etapa de instrucción es el sistema auténticamente acusatorio, que representa una solución equilibrada en la cual son considerados debidamente no sólo el interés estatal en el esclarecimiento y sanción de los hechos delictivos, sino que también, y con el mismo vigor, los derechos de las personas"; Horvitz, M. I. - López, J., cit. (n. 4), I, pp. 123 y 197, por su parte, señalan que con la atribución de la dirección exclusiva de la investigación al Ministerio Público se optó por el diseño de la investigación más compatible con el principio acusatorio y con el respeto de las garantías del debido proceso, agregando luego que en definitiva se optó por un "modelo de rol judicial más propio de los sistemas adversariales”; y Duce, M. - Riego, C., cit. (n. 14), pp. 96-97, ratifican que este modelo de instrucción por el cual opta el CPP., es bastante cercano a una idea tripartita de procedimiento, es decir, en la que al menos desde un cierto momento de la investigación (cuando ésta es judicializada), el proceso se construye con la participación permanente de estos tres actores en las distintas actividades y diligencias. 
Ahora bien, si es efectivo que el principio acusatorio tiene su fundamentofin en la necesidad de imparcialidad del juzgador, entonces dicho principio adquiere apoyatura constitucional en el del derecho chileno en el artículo $19 \mathrm{~N}^{\circ} 3$ inciso $6^{\circ}$ de nuestra Carta Máxima ${ }^{41}$, que consagra el derecho a un proceso justo, y que recoge según es unánime nuestra doctrina, la garantía de imparcialidad del órgano jurisdiccional ${ }^{42}$. En esa línea se valora al principio acusatorio como un medio o forma a través de la cual se logra el establecimiento de un órgano jurisdiccional imparcial en el proceso penal ${ }^{43}$. Pues bien, el influjo del principio acusatorio y consecuentemente del resguardo de la imparcialidad del juzgador que se busca por su intermedio será determinante en la delimitación de las posibilidades de supervisión y enmienda por parte del órgano jurisdiccional de la pasividad o inadecuación del Ministerio Público en la etapa de instrucción preparatoria del ejercicio de la acción penal, como en su ejercicio mismo.

\section{SOPORTES DEL ESQUEMA ACUSATORIO NACIONAL}

Esta configuración acusatoria de nuestro proceso penal, que tiende a limitar el radio de acción de los Tribunales como garantes del principio de obligatoriedad de la acción penal, se ve apuntalada por diversas vallas que el propio ordenamiento le levanta a los jueces y que les impiden en último término la efectiva aplicación de la ley penal sustantiva. Al respecto, analizaremos suscintamente tres puntos que consideramos relevantes de considerar: las limitaciones constitucionales y legales a la supervisión judicial de la no promoción de la persecución penal por el Ministerio Público; el necesario margen de discrecionalidad técnica que requiere la labor del Ministerio Público; y, las restricciones al derecho de defensa que conlleva una aguda intervención judicial.

${ }^{41}$ Del Río, C., Los poderes, cit. (n. 15), pp. 74 ss. Además deben mencionarse los artículos 8.1 CADH. y 14.1 PIDCP., que consagran el derecho a un juez imparcial, derechos recividos en Chile vía artículo 5 inciso $2^{\circ} \mathrm{CPol}$.

${ }^{42}$ Fernández GonzÁLEz, Miguel Ángel, La nueva justicia penal frente a la Constitución (Santiago, LexisNexis, 2006), p. 79; Evans de la Cuadra, Enrique, Los derechos constitucionales (2a edición, Santiago, Editorial Jurídica de Chile, 1999), II, pp. 146; Chahuán, S., cit. (n. 34), p. 24. Carocca Pérez, Alex, Las garantías constitucionales en el sistema procesal chileno, en Ius et praxis, 3 (1997) 2, p. 191, acota que ésta constituye una garantía cuyo reconocimiento resulta difícil encontrar en la Constitución, situándola en el derecho a ser juzgado por el tribunal predeterminado por la ley, que incluiría la prohibición a ser juzgado por cualquier organismo que no reúna las características esenciales de aquéllos, entre las que se halla la imparcialidad.

${ }^{43}$ Horvitz, M. I. - López, J., cit. (n. 4), I, p. 44. 


\section{Las limitaciones constitucionales y legales a la supervisión judicial de la} no promoción de la persecución penal por el Ministerio Público.

El principio de exclusividad de la función jurisdiccional, por el cual, conforme al artículo 76 CPol. "la facultad de conocer de las causas civiles y criminales, de resolverlas y de hacer ejecutar lo juzgado pertenece exclusivamente a los tribunales establecidos por la ley" (reiterado en el artículo $1^{\circ} \mathrm{COT}$.), en su vertiente negativa u obstativa inhibe a los jueces de realizar actividad de instrucción o acusación, por cuanto en ellas no hay ejercicio de labor jurisdiccional, no se enjuicia ni se hace ejecutar lo juzgado ${ }^{44}$. Aunque nuestra Carta Constitucional no recoja este aspecto negativo de la exclusividad en forma particularizada -a diferencia del texto español-, sí lo residencia a nivel general en su artículo 7 inciso $2^{\circ}$, en tanto prohíbe, aun a pretexto de circunstancias extraordinarias, atribuirse otra autoridad o derechos que los que expresamente se les hayan conferido en virtud de la Constitución o las leyes, además de acogerlo a nivel legal en el $4^{\circ}$ del Código Orgánico de Tribunales, que veda al Poder Judicial "mezclarse en las atribuciones de otros poderes públicos” ${ }^{\prime 5}$. Como forzoso complemento al carácter negativo de la exclusividad de la jurisdicción que venimos comentando, hoy nuestra preceptiva constitucional reserva las tareas de dirigir la investigación oficial y de acusar -esto último no monopólicamente- a una institución autónoma e independiente como el Ministerio Público ${ }^{46}$.

${ }^{44}$ Declaran en España este sentido negativo de la exclusividad que se desprende de las normas constitucionales, entre otros, De Diego Díez, Luis Alfredo, El principio "el que instruye no debe juzgar" como garantía de imparcialidad en el enjuiciamiento penal, en AA.VV., Crisis de la justicia y reformas procesales (Madrid, Centro de Publicaciones, Ministerio de Justicia, 1988), p. 568; Montero Aroca, Juan y otros, Derecho jurisdiccional. Proceso penal (Barcelona, Bosch, 1991), III, p. 13; Moreno Catena, Víctor, El enjuiciamiento de delitos menos graves. Apunte sobre la imparcialidad del juzgador, en Boletín de Información del Ministerio de Justicia, 1468 (1987), p. 2758; y Moreno, V. y otros, Introducción, cit. (n. 16), pp. 87-88. Más sobre esta discusión en la doctrina española, en MARTín, José, cit. (n. 14), pp. 194-195; y, Gómez, J. L., La instrucción, cit. (n. 14), pp. 154 ss.

${ }^{45}$ Este precepto consagraría el sentido negativo de la independencia judicial, cfr. Maturana, C. - Montero, R., cit. (n. 19), I, p. 114. Tendría incluso protección penal en el artículo $222 \mathrm{CP}$., el cual sanciona al "empleado del orden judicial que se arrogare atribuciones propias de las autoridades administrativas o impidiere a éstas el ejercicio legítimo de las suyas".

${ }^{46}$ El Ministerio Público fue creado e introducido a la Constitución por la Ley de Reforma Constitucional $\mathrm{N}^{\circ} 19.519$, de 16 de septiembre de 1997, regulándose en el actual capítulo $7^{\circ}$ sus bases organizativas y funcionales, las que la Ley $\mathrm{N}^{\circ} 19.640$ Orgánica Constitucional del Ministerio Público de 15 de octubre de 1999 desarrolla en forma extensa y bastante reglamentaria. Para un estudio detallado de esta institución, véase: Duce, M. - Riego, C., cit. (n. 14), pp. 533 ss., quienes indican que con la ubicación 
Con lo anterior no queremos expresar que todas las actividades que se practiquen en las fases previas y preparatorias al juicio carezcan de naturaleza jurisdiccional, pues parece haber cierto consenso en que en la etapa de instrucción hay un entramado de actividades jurisdiccionales y administrativas, correspondiendo indiscutiblemente a las primeras, y por tanto privativas de los jueces, la aprobación de las actuaciones que priven al imputado o a terceros del ejercicio de los derechos que la Constitución asegura, o lo restrinjan o perturben (artículo 83 inciso $3^{\circ} \mathrm{CPol}$. $)^{47}$.

institucional del Ministerio Público como un órgano autónomo o extrapoder se intentó evitar los peligros de judicialización y politización de la institución. También CArocCa PÉRez, Alex, El nuevo sistema procesal penal ( $3^{a}$ edición, Santiago, LexisNexis, 2005), pp. 17 ss. Chile sigue entonces el modelo italiano, así como el de la mayoría de los países de la región, como Argentina, Bolivia, El Salvador, Guatemala, Honduras, Perú, Paraguay y Venezuela. Un examen constitucional de la autonomía del Ministerio Público en Silva Bascuñán, Alejandro, Tratado de Derecho constitucional (2a edición, Santiago, Editorial Jurídica de Chile, 2002), VIII, pp. 207 ss.; Fernández, M. A., La nueva justicia, cit. (n. 42), pp. 180 y ss.; y Verdugo Marinkovic, Mario - Pfeffer Urquiaga, Emilio - Nogueira Alcalá, Humberto, Derecho constitucional (2a edición, Santiago, Jurídica de Chile, 1999), II, pp. 262 ss.

${ }^{47}$ En España se ha sostenido la constitucionalidad de la instrucción judicial, no obstante no ser ésta una actividad jurisdiccional, basado en el artículo 117.4 de su texto supremo, el cual autoriza a los juzgados y tribunales a ejercer, junto a la potestad jurisdiccional, las demás funciones que "expresamente" les sean atribuidas por Ley "en garantía de cualquier derecho”, así, por ejemplo, Ortells Ramos, Manuel, La instrucción por el Ministerio Público (Reflexiones sobre el estado de la cuestión en derecho español), Ponencia en Seminario internacional "Justicia y sociedad", organizado por el Instituto de Investigaciones Jurídicas de la UNAM y por la Procuraduría General de la República. Publicación, UNAM, México, 1994), p. 479. En opinión de GómEZ, J. L., El Ministerio Fiscal, cit. (n. 14), p. 30, constituiría ejercicio de potestad jurisdiccional las siguientes resoluciones: medidas cautelares, restricciones de derechos sin carácter cautelar generalmente instrumentales respecto a la obtención y examen de fuentes de prueba, admisión de la acusación y práctica anticipada de prueba. Actividades realizadas durante la instrucción que no revisten naturaleza jurisdiccional son las dirigidas a averiguar contra qué persona se puede formular la acusación, de qué hechos se le puede acusar o de qué fuentes de prueba se dispone para fundamentar la acusación. En igual sentido, Moreno, Víctor, Presente, cit. (n. 14), pp. 87-88. Ruiz Vadillo, Enrique, La actuación del Ministerio Fiscal en el proceso penal, en EL MISmo, Estudios de Derecho procesal penal (Granada, Comares, 1995), pp. 77-78, confía las tareas de descubrimiento de los hechos aparentemente delictivos y sus responsables así como la preparación de la acusación al Ministerio Fiscal, y reserva el aseguramiento de sus resultados a la autoridad judicial. Dando cuenta de esta discusión en España, véase: Gimeno SendRa, Vicente - Moreno Catena, Víctor - Cortés Domínguez, V., Derecho Procesal Penal (3a edición, Madrid, Colex, 1999), pp. 338-339; y Gómez, J. L.Luis, La instrucción, cit. (n. 14), pp. 150 ss. El cambio que supuso en Alemania la derogación del sistema de fase sumarial en manos del juez instructor (en el año 1974), según da cuenta GómEZ, J. L., 
Los precitados artículos 76 y 83 en conjunto con los artículos $6^{\circ}$ y $7^{\circ}$ CPol. ${ }^{48}$, que consagran el sometimiento a un sistema de legalidad, obstarían cualquier inteligencia de las normas legales del ordenamiento adjetivo que implique extender el desempeño jurisdiccional de los Tribunales hacia actividades de instrucción y acusación que la ley ha reservado al Ministerio Público. De ese modo, el encargo del legislador a los jueces de garantía para

El proceso penal alemán, cit. (n. 23), p. 74, hizo surgir dudas en este punto de naturaleza constitucional, por entenderse que la nueva relación Ministerio Fiscal - juez investigador, podría violar la independencia judicial consagrada en el artículo 97.1 de la Constitución alemana. El Tribunal constitucional Federal alemán, sin embargo, ha declarado que no se produce tal violación, porque el Juez Investigador no ejerce en estos casos actividad jurisdiccional, sino administrativa, siendo un órgano que constitucionalmente viene obligado a prestar ayuda administrativa, en base al artículo 35 CPolAl. En Portugal se presenta una situación especial, pues su Constitución de 1976 prescribe por un lado, que las investigaciones preliminares deben ser conducidas enteramente bajo la responsabilidad de un juez (artículo 32.4 CPolPort.), y por otro, que el procedimiento criminal debe poseer una estructura acusatoria (artículo 32.5 CPolPort.), lo que obligó al codificador de 1988 a procurar un proceso que cumpliera ambas exigencias, y que justifica la mayor injerencia que se impone al Juez en la instrucción. Sobre la discusión en Argentina respecto al no ejercicio de jurisdicción en la fase de investigación, véase: Cafferata Nores, José, Ministerio Público Fiscal: perfil funcional, situación institucional y persecución penal (en la nueva legislación argentina), en EL MISMO, Cuestiones actuales sobre el proceso penal ( $3^{\text {a }}$ edición, Buenos Aires, Editores del Puerto, 2000), pp. 77-79. BInder, Alberto, Crisis y transformación de la justicia penal en Latinoamérica, en AA.VV., Reformas procesales en América Latina (Santiago, Corporación de Promoción Universitaria, 1993), p. 80, estima que dos elementos delimitan el terreno de lo propiamente jurisdiccional: "en primer lugar, la solución del conflicto de fondo que ha motivado el proceso. Además, la resolución de las incidencias que se relacionan con dicho motivo o con la correcta estructuración del proceso. En segundo lugar, la preservación de las garantías judiciales". Pero no sólo la determinación de la coerción procesal antes de la decisión sobre la pena debiera ser patrimonio inalienable de la jurisdicción en la fase de instrucción, sino, también aquellas decisiones definitivas que en algún sentido pongan fin al asunto de que se trata y puedan adquirir el estatus de cosa juzgada material, así como el sobreseimiento. Catalogando la emisión de este último tipo de decisiones como nota característica de aquello que define a un tribunal, véase: MAIER, J., Derecho procesal penal, cit. (n. 26), p. 43. En el ámbito nacional Otero Lathrop, Miguel, El Ministerio Público, en AA.VV., El nuevo proceso penal chileno (Concepción, Universidad de Concepción, Facultad de Ciencias Jurídicas y Sociales, Departamento de Derecho Procesal, 2000), p. 62, aclara sobre este punto que la jurisdicción no comprende la investigación, de lo contrario no existiría jurisdicción civil, donde el órgano jurisdiccional carece de facultades investigadoras.

${ }^{48}$ Artículo 6 CPol.: "Los órganos del Estado deben someter su acción a la Constitución y a las normas dictadas conforme a ella [...]"; artículo 7 CPol.: "Los órganos del Estado actúan válidamente previa investidura regular de sus integrantes, dentro de su competencia y en la forma que prescriba la ley". 
"conocer y resolver todas las cuestiones y asuntos que este Código [Orgánico de Tribunales] y la ley procesal penal les encomienden" (artículo 14 g COT.), debe interpretarse de manera tal que las específicas actividades que la ley procesal les adjudique no se analoguen a la instrucción o acusación, y así no confrontar las normas constitucionales ya conocidas ${ }^{49}$. Súmese a todo lo dicho la dificultad que el principio de pasividad, consagrado en el artículo 10 COT.$^{50}$, significará para alguna actividad del Tribunal que pretenda inmiscuirse en la labor requirente del Ministerio Público, más aun si se desarrolla oficiosamente sin expresa autorización legal ${ }^{51}$.

$\mathrm{Al}$ respecto, se ha explicado con precisión y contundencia que lo que subyace aquí es una determinación de competencias en orden a que, son el Ministerio Público y el legislador los que determinan la política criminal del Estado, por lo que el fiscal ordena de acuerdo a dicha política lo que corresponda en esta fase; de esta manera, y entiéndase de una vez por todas, no se le entrega al magistrado el control del éxito de la instrucción, como para que tenga el poder de enderezar en opinión suya la investigación (no es el representante ni contralor del interés público de la investigación, sino el garante de los derechos públicos subjetivos). Como consecuencia de este

${ }^{49}$ Ya en 1997, Alvear, María Soledad, Los principios que dan consistencia al nuevo sistema de enjuiciamiento criminal, en AA.VV., El nuevo proceso penal chileno (Concepción, Universidad de Concepción, Facultad de Ciencias Jurídicas y Sociales, Dept. de Derecho Procesal, 2000), p. 14, señalaba que, en sujeción al principio acusatorio que regía el nuevo proceso penal, "los jueces debían evitar cualquiera actuación suya o cualquiera interpretación que los aparte del estricto papel de terceros imparciales que el principio acusatorio les asigna". DE LA BARRA, Rodrigo, Sistema inquisitivo versus adversarial; Cultura legal y perspectivas de la Reforma Procesal en Chile, en Ius et Praxis, 5 (1999) 2, p. 146, anticipaba antes de la aprobación del CPP., que "la interacción más compleja que se puede llegar a vislumbrar durante el período de implementación del sistema, es la relación entre los nuevos fiscales y los jueces", entre otras razones, porque "es dable pensar que los jueces, acostumbrados a la duplicidad o multiplicidad de roles, asumirán las deficiencias en el proceso y desarrollen su rol inconcluso”. Es así como la preocupación del legislador por deslindar claramente el campo de las potestades del Ministerio Público y de los JG, llevó incluso a sustituir la denominación original de “juez de control de instrucción” a "juez de garantía”, a fin de evitar interpretaciones que entendieran que el juez tenía que determinar el desarrollo de la instrucción, destacándose que su rol es el de protector de las garantías constitucionales, cfr. HoyOS DE LA Barrera, María Teresa, Principios fundamentales del nuevo proceso penal, en Revista de Derecho Procesal, 20 (2005), p. 52.

${ }^{50}$ Artículo 10 COT.: "Los tribunales no podrán ejercer su ministerio sino a petición departe, salvo los casos en que la ley los faculte para proceder de oficio".

${ }^{51}$ Como discierne Salas, J., cit. (n. 34), p. 26, sea que el Juez de Garantía "actúe como contralor de la legalidad de los actos de investigación del Ministerio Público o como juez fallador en su sentido estricto, no podrá actuar o resolver por iniciativa propia a falta de norma legal expresa que lo autorice". 
sentido, en el evento de producirse una antinomia o laguna acerca de un punto en materia de estas competencias, la decisión que resuelva sobre el punto habrá de inclinarse a favor de la jurisdicción (en sentido amplio) constitucional del fiscal ${ }^{52}$.

Esta estricta separación de funciones y potestades, conlleva radicar en sede administrativa -en el Ministerio Público-, la decisión de aspectos que incidirán sustancialmente en la forma, contenido y extensión de la declaración del derecho penal por parte del tribunal, ya sea inhibiendo dicha declaración, o determinándola o restringiéndola. Como enseña Tavolari, el ser el Ministerio Público un órgano del Estado con autonomía que ningún Poder puede desconocer, genera un estado dual en el que, aun siendo la regla general que los tribunales no resulten jurídicamente vinculados por las peticiones del fiscal, "no faltan los episodios en los que la respuesta del legislador consiste en privilegiar las decisiones del Ministerio Público" 53 . Obsérvese que en el tránsito de un sistema procesal inquisitivo a uno acusatorio, se produce un importante cambio en el ejercicio del poder práctico por parte del juez. En el esquema inquisitivo, el juez asume mucho poder "administrativo" y delega poder "judicial"; mientras en la estructura acusatoria ocurre lo contrario, pero, paradójicamente - porque el Poder Judicial es un poder de mayor fuerza y entidad que el administrativo-, esto es percibido por los jueces como una pérdida de poder ${ }^{54}$.

Pero no hay aquí involucrado sólo un asunto de competencias constitucionales, sino además de garantías fundamentales. Cuando el carácter acusatorio se traduzca para el justiciable en garantía de imparcialidad del tribunal, este derecho proclamado en los tratados internacionales suscritos y vigentes en nuestro territorio ${ }^{55}$, constitucionalizado a través del artículo 5 inciso $2^{\circ} \mathrm{CPol}$., determinará el contenido de las disposiciones meramente legales que regulan el enjuiciamiento penal, volviéndose una barrera infranqueable para interpretaciones mediante las cuales los Jueces se arroguen funciones instructoras o requirentes.

La primera consecuencia que deriva de lo expuesto es que los Tribunales no pueden ejercer facultades inquisitivas que no estén reconocidas "expresamente" en el texto legal, ni tampoco actuarlas de oficio si la ley las condiciona al "requerimiento de parte". Y el segundo corolario es que las

${ }^{52}$ Gandulfo, E., cit. (n. 14), p. 423.

${ }^{53}$ Tavolari, R., cit. (n. 34), p. 239.

${ }^{54}$ Binder, A., Ideas, cit. (n. 13), p. 52.

${ }^{55}$ Artículos 8.1 CADH. y 14.1 PIDCP. Para Maturana, C. - Montero, R., cit. (n. 19), I, p. 115, el derecho a ser juzgado por un tribunal imparcial es una garantía del debido proceso consagrada en el artículo $19 \mathrm{~N}^{\circ} 3$ inciso $6^{\circ} \mathrm{CPol}$., y que además se recoge expresamente en el artículo $1^{\circ} \mathrm{CPP}$. 
facultades inquisitivas previstas en la ley no pueden interpretarse de suerte tal que su ejercicio vulnere los principios mencionados, es decir, tales facultades sólo serán legítimas en la medida que no afecten el contenido del principio acusatorio entendido como manifestación de la separación de competencias constitucionales entre el Ministerio Público y la judicatura y en salvaguarda de la imparcialidad del órgano jurisdiccional. De esa manera, cuando existan dos o más interpretaciones posibles de este tipo de facultades, se debe preferir aquella que mejor responda y resguarde las exigencias del principio acusatorio $^{56}$.

Como expresa Bovino ${ }^{57}$, cualquier mecanismo de control que se adopte para asegurar el cumplimiento del principio de legalidad procesal no puede desconocer o reducir el valor de otros principios de rango normativo superior, tales como la garantía de imparcialidad y el principio de división de poderes. Ello significa que el interés de perseguir todos los delitos está subordinado al respeto de otros intereses de mayor jerarquía axiológica. En consecuencia, agrega el mismo autor, "cualquier mecanismo de control que se adopte para asegurar el cumplimiento del principio de legalidad no puede desconocer o reducir el valor de esos intereses considerados más valiosos. Así, si un mecanismo determinado, significa la imposibilidad de que el tribunal actúe de modo imparcial, éste debe ser desestimado, pues la imparcialidad es un valor que tiene mayor jerarquía normativa que la del principio que establece la obligación de perseguir todos los hechos punibles".

En sintonía con lo que se ha venido alegando, $\mathrm{Maier}^{58}$ agrega que frente a lagunas legislativas en estas materias -como las que abundan en nuestro CPP.-, "resulta necesario para resolverlo legislativamente, tomar conciencia del conflicto entre la regla que impone el control jurisdiccional de la aplicación del principio de legalidad por parte de la fiscalía y la máxima que impide a los tribunales obrar de oficio, en homenaje a su imparcialidad. Sólo si se puede afirmar que alguna de ellas tiene jerarquía superior a la otra, por tanto, si deriva de alguna regla constitucional, es posible resolver el conflicto de

${ }^{56}$ En esto hemos seguido, en líneas gruesas, a Bovino, Alberto, Proceso penal, cit. (n. 25), p. 22. DucE, M. - y Riego, C., cit. (n. 14), p. 105, reafirman que la garantía de imparcialidad también cubre el actuar de los jueces de instrucción respecto de las decisiones que éstos adoptan durante la etapa de investigación preliminar. Piedrabuena, G., Rol del Ministerio, cit. (n. 1), p. 12, consistente con lo que se ha venido exponiendo, manifiesta que "la interpretación y/o aplicación que se haga de las nuevas normas del Código Procesal Penal, nunca podrá interferir con la misión constitucional de los fiscales para dirigir soberanamente sus investigaciones y determinar cuándo resuelven ejercer la acción penal pública, sea a través de la formalización de la investigación o de la acusación en contra del imputado."

${ }^{57}$ Bovino, A., Proceso penal, cit. (n. 25), p. 19.

${ }^{58}$ Maier, J., Derecho procesal penal, cit. (n. 26), p. 345. 
lege lata." De ese modo, el interés social o colectivo en la persecución penal de los hechos punibles, recepcionado sólo a nivel meramente legal a través de los principios de obligatoriedad de la acción penal y de oficialidad, debe inclinarse y ceder cuando conflictúa con derechos y garantías constitucionales reconocidos al imputado en el enjuiciamiento penal, si de lo contrario se erosiona el carácter acusatorio del proceso -y por consiguiente, la imparcialidad del juzgamiento-.

Ni siquiera la antinomia entre el derecho al enjuiciamiento imparcial del imputado, y el derecho a la acción penal, a la jurisdicción, o a la tutela judicial efectiva reconocidos al ofendido, todas con reconocimiento constitucional, ya sea directamente o a través de los tratados internacionales, conmueve lo afirmado arriba, ya que tal antinomia, de existir, fue resuelta a nivel legal por el legislador en el artículo 5 inciso $2^{\circ} \mathrm{CPP}$., que ordena una interpretación restrictiva y prohíbe la aplicación por analogía de las disposiciones que autorizan la restricción de la libertad o de otros derechos del imputado o del ejercicio de alguna de sus facultades ${ }^{59}$. De ese modo, una interpretación que amplíe las facultades de los tribunales más allá de lo propiamente jurisdiccional en resguardo del derecho a accionar de la víctima (forzando la formalización o la modificación agravatoria de un requerimiento o acusación, por ejemplo), está vedada si afecta, restringe o pone en riesgo el derecho del encausado a un enjuiciamiento imparcial. No puede soslayarse que ninguna norma parecida al artículo 5 precitado protege el derecho a ejercer la acción penal del ofendido, opción político-criminal que nos parece válida, así como la mesurada intervención que el legislador confía al querellante a lo largo de todo el proceso, pues de ese modo se evita que la intervención de la supuesta víctima en el procedimiento penal represente un menosprecio (desequilibrio) intolerable para los derechos defensivos del imputado o, cuando menos, una carga demasiado pesada para él ${ }^{60}$. Si algunos pretenden reconfigurar la forma en que nuestro legislador definió la tensión entre los derechos del imputado y el interés público por la represión, como acierta otra vez Bovino,

${ }^{59}$ Este precepto se encuadra en la doctrina que propugna a las normas del proceso criminal no susceptibles ni de interpretación extensiva ni de analogía, en cuanto restrictivas de la libertad e incidentes en la esfera de sagrados intereses individuales, cfr. Clariá, Jorge, cit. (n. 4), pp. 114-115; y Fairén Guillén, Víctor, Doctrina general del proceso Penal. (Hacia una teoría y Ley procesal generales) (Barcelona, Bosch, 1990), p. 65.

${ }^{60}$ Estas son las razones por las que MAIER, J., Derecho procesal penal, cit. (n. 26), p. 626 , se demuestra partidario por la solución de la querella adhesiva. Reitera esta inclinación el autor en Democracia, cit. (n. 14), p. 46. 
ello "presupone, entonces, una nueva determinación del valor concedido al interés invidividual en el contexto procesal" ${ }^{61}$.

\section{El necesario margen de discrecionalidad técnica que requiere la labor del Ministerio Público.}

Avanzando a otro orden de ideas de menor calado constitucional, cada vez que el Fiscal decide si los antecedentes del hecho punible del cual ha tomado noticia, permiten desarrollar actividades conducentes al esclarecimiento de los hechos, formalizar la investigación o formular la acusación, y cómo calificar jurídicamente la materia fáctica en cuestión, está realizando juicios de procedencia que el legislador ha administrativizado y excluido de la actividad jurisdiccional $^{62}$. Si aceptamos que ya la propia interpretación de la ley no es nunca una actividad solamente recognoscitiva, sino que siempre es el fruto de una elección práctica respecto de hipótesis interpretativas alternativas, y que esta elección, más o menos opinable según el grado de indeterminación de la previsión legal ${ }^{63}$, concluye inevitablemente en el ejercicio de un poder

${ }^{61}$ Bovino, Alberto, Proceso penal, cit. (n. 25), p. 28.

${ }^{62}$ Como señala Zagrebelsky, Vladimir, cit. (n. 21), p. 118, "es evidente que el ministerio público estará obligado a ejercitar la acción penal solamente cuando, en un momento lógicamente precedente, haya considerado (en cierto modo discrecionalmente) encontrarse en presencia de todos los elementos que corresponden a la norma incriminadora”. En relación al proceso español, agrega De Diego Díez, L., La conformidad, cit. (n. 32), p. 220, que "lo que sí ha existido desde siempre es un margen de discrecionalidad legal que el Ministerio Fiscal ha de ponderar a la hora de "arriesgar" o no la acusación y en qué medida. En primer lugar, la obligatoriedad del ejercicio de las acciones penales a que se refiere el artículo 105 LECrim., tiene su límite en aquéllas "que consideren procedentes". Nada impide, por tanto, que el Fiscal valore conforme a su criterio los elementos de hecho y de derecho que han de servir para fundamentar la acusación, realizando, a tal efecto, un juicio doble: de una parte, sobre la "probabilidad" de la perpetración de un hecho con caracteres de delito y sobre la responsabilidad criminal del sujeto pasivo de la acción; y, de otro lado, ha de apreciar objetivamente, según las circunstancias del caso, e incluso a pesar de su propio convencimiento, si la prueba de la culpabilidad es posible en función del material probatorio de que dispone o, por el contrario, está desprovista de toda expectativa de éxito".

${ }^{63}$ Especialmente cuando nos enfrentamos a lo que la doctrina administrativa denomina como "conceptos jurídicos indeterminados", esto es, conceptos vagos, imprecisos, inconcretos, que no delimitan exactamente el ámbito de la realidad a que se refieren, no obstante lo cual su operación aplicativa no es volitiva sino puramente cognitiva, plano intelectivo éste en el que no existe discrecionalidad, y que por tanto, al remitir siempre a una única solución justa, está sujeta al control judicial, MuÑoz MACHAdo, Santiago, Tratado de Derecho administrativo y Derecho público general (Madrid, Thomson-Civitas, 2004), I, pp. 530 ss. García de Enterría, Eduardo - Fernández, Tomás Ramón, Curso de Derecho administrativo (12 a edición, Madrid, Thomson-Civitas, 2004), I, pp. 465 ss., entre tantos otros, propugnan que este tipo de conceptos sólo permite 
en la calificación jurídica del factum juzgado ${ }^{64}$, especificar o concretar el deslinde entre la discrecionalidad técnica y la discrecionalidad política ${ }^{65}$ no

una "unidad de solución justa" en cada caso, a la que se llega mediante una actividad de cognición, objetivable por tanto, y no de volición. Parte de la doctrina administrativa ha cuestionado esta conclusión, cfr. SÁnchez Morón, Miguel, Discrecionalidad administrativa y control judicial (Madrid, Tecnos, 1994), pp. 116 ss. Sobre la aplicación de la doctrina de los conceptos jurídicos indeterminados en materia penal, véase: DELGADO BARRIO, Javier, El principio de oportunidad en el proceso penal, en AA.VV, La reforma del proceso penal. II Congreso de Derecho Procesal de Castilla y León (Madrid, Ministerio de Justicia, 1989), pp. 314 ss.

${ }^{64}$ FerRajOLI, L., cit. (n. 12), pp. 546-547, complementa que la verificación de una aserción empírica exige decisiones argumentadas; la prueba empírica de los hechos penalmente relevantes no es en realidad una actividad solamente cognoscitiva, sino que siempre forma la conclusión más o menos probable de un procedimiento inductivo cuya aceptación es a su vez un acto práctico que expresa un poder de elección respecto de hipótesis explicativas alternativas. Concluye resignadamente entonces que "la legitimidad de la función judicial, que reside en los vínculos que le impone la ley en garantía de su carácter cognoscitivo y para tutela de los derechos de los ciudadanos, es siempre parcial e imperfecta. Sabemos, en efecto, que tal función, incluso en el mejor de los sistemas, no es solamente cognoscitiva sino también, en alguna medida, potestativa, a causa de la discrecionalidad que siempre interviene en la interpretación de la ley, en la valoración de las pruebas, en la connotación del hecho y en la determinación de la medida de la pena. El juez, en suma, [...], no es 'bouche de la loi', ni siquiera en su modelo teórico e ideal; y lo es aún menos en su trabajo práctico, puesto que la ley le confiere espacios más o menos amplios de poder de disposición. Por otra parte, los titulares de la acusación pública lo son todavía menos, al ser el de la iniciativa penal el momento más potestativo de toda la actividad procesal: aquel en el cual (...) es menor el saber y mayor el poder." En el mismo sentido, respecto de la conformidad española, De Diego Díez, L., La conformidad, cit. (n. 32), p. 221; y Andrés, P., Por un Ministerio, cit. (n. 12), pp. 448-450, para quien debe reconocerse "una incidencia inevitable de márgenes de discrecionalidad en la actividad de quienes como el juez y el fiscal deben aplicar disposiciones jurídicas." No podemos dejar aquí de remitirnos a las valiosas contribuciones de Hart, Herbert. L. A., El concepto de derecho (traducción castellana de G. R. Carrió, Buenos Aires, Abeledo-Perrot, 1992), pp. 155 y ss., para quien la inevitabilidad de este margen de actuación dentro del sistema legal es fundamentado en la abierta textura de la ley.

${ }^{65}$ Conforme explica Díez-Picazo, Luis, cit. (n. 4) p. 15, la discrecionalidad política o de oportunidad consiste en la posibilidad de ejercer la acción penal según criterios extrajurídicos, implicando por tanto un juicio de pura conveniencia en virtud del cual se decide si el ejercicio de la acción penal es apropiado con respecto a ciertos objetivos políticos. La discrecionalidad técnica o interpretativa, en cambio, presupone una operación de valoración de hechos e interpretación de normas en virtud de la cual se decide si se está técnicamente en condiciones de ejercer la acción penal y cuál es el modo más adecuado de hacerlo. Al respecto, Gómez, E. - Herce, V., cit. (n. 4), pp. 97-98 nos enseñan que lo primero que tiene que apreciar el Fiscal (mediante una calificación jurídica) es si el hecho es constitutivo de delito, pues la acción sólo procede cuando lo 
resulta fácil en algunos casos de zonas jurídicas grises o de penumbra que aparentan ser intermedias o superpuestas ${ }^{66}$.

Mientras el Ministerio Público se valga de estos juicios de probabilidad sobre la procedencia de la acción penal en la res iudicanda, cabrá en efecto, un cierto margen de discrecionalidad técnica que podría permitir situarse al fiscal dentro de los presupuestos cuya concurrencia la ley exige para autorizar una decisión de oportunidad -las llamadas salidas alternativas-, o incluso para facilitar el acercamiento del fiscal a alguna postura defensiva y el logro de un procedimiento consensuado. En estos supuestos, entonces, el juez de garantía únicamente verificaría la razonabilidad jurídica de la calificación de los hechos efectuada por el fiscal, controlando su plausibilidad dogmática, pero no ejecutaría un control de legalidad fuerte que conlleve un pronunciamiento autónomo o la expresión de una opinión jurídica propia sobre el fondo de la calificación jurídica de los hechos materia de la investigación ${ }^{67}$.

sea. Ha de considerar después si puede aportar al menos indicios racionales de que se haya perpetrado, y sobre todo, si existen motivos suficientes para acusar a determinada persona; en suma, si la prueba del factum y de la participación del inculpado aparece como posible, y aun (en un momento ulterior) como probable. Pues en otro caso la acusación no tiene base, y sería antijurídica.

${ }^{66}$ De algunas de estas zonas da cuenta Couso Salas, Jaime, Oportunidad versus legalidad: entre economía político-criminal, despenalización, prevención y principios garantistas, en Cuadernos de análisis jurídico, 39 (1998), pp. 185-186, cuando explica que, "como sostiene Roxin, el principio de legalidad procesal-penal [o de obligatoriedad de la acción penal, como hemos preferido llamarlo] también tiene relación con el mandato de determinación de las prohibiciones penales, vinculado al principio de legalidad penal, pues en la medida que los criterios de oportunidad ensayados por el fiscal pasen a ser más decisivos que la descripción de la conducta típica por parte del legislador, ya no es tan claro que sea el legislador quien está decidiendo en forma previa y precisa (las ulteriores precisiones las realiza el fiscal) la conducta puede sancionarse penalmente. Ello es cierto particularmente si se tiene en cuenta que el moderno proceso de expansión de las conductas incriminadas [...], usa de técnicas legislativas más alejadas del mandato de determinación, como la introducción de tipos abiertos, cargados de referencias normativas (entre otras, la propia noción del bien jurídico colectivo que se supone lesionado, así como la noción de 'puesta en peligro' de dichos bienes); pues, entonces, la facultad del fiscal de seleccionar una parte de esos delitos de acuerdo a criterios más o menos vagos e inseguros, se convierte en la verdadera regla definidora del comportamiento que se castiga".

${ }^{67}$ Mera Figueroa, Jorge, Discrecionalidad del Ministerio Público, calificación jurídica y control judicial, en Informe de Investigación, No 1 al 15, 1999-2003 (Santiago, Centro de Investigaciones Jurídicas, Facultad de Derecho Universidad Diego Portales, 2004), pp. 240 ss. A juicio del autor, esta opción se condice con los objetivos políticocriminales de los mecanismos de selección de casos y de salidas alternativas del nuevo proceso penal, que son fundamentales para un eficaz funcionamiento del sistema, $y$, además, con la circunstancia de que sea el fiscal el que está en mejores condiciones de 
De lo contrario, se corre el riesgo de suponer al Ministerio Público incluido en el poder judicial y bajo la supervisión directa de los jueces al ejecutar su labor requirente, imponiéndole los criterios jurisprudenciales utilizados por la judicatura, por vía directa o indirecta ${ }^{68}$.

Ahora bien, como ya se habrá reparado, lo problemático de este planteamiento obedece a que el Ministerio Público suele tamizar este juicio de procedencia con juicios de oportunidad, lo que le permite escamotear o sustraerse a los controles judiciales dispuestos por el legislador para evitar el injustificado abandono de la persecución ante la dificultad de develar cuando aquéllos encubren a éstos. Un excesivo rigor o celo judicial para revertir la discrecionalidad del fiscal en ámbitos no autorizados por la ley, arriesga dispersarse a áreas en las que legitimamente el persecutor público puede dictaminar autónomamente un juicio de procedencia sobre la acción penal (los márgenes insuprimibles de opinabilidad en la interpretación de la ley y valoración del material probatorio), sustituyendo indebidamente el criterio administrativo por el judicial ${ }^{69}$.

realizar las calificaciones postuladas en dichos mecanismos, las que resultan de la comparación de las normas legales y los hechos que el fiscal se encuentra en condiciones de acreditar en el juicio oral, pronóstico que él está en mejores condiciones de realizar que el juez. Interpretar de otra manera las facultades de control jurídico del juez de garantía, continúa el autor en comento, contiene resabios inquisitivos, puesto que es el juez el que decide sobre la continuación de la investigación en casos en que no se trata de amparar las garantías ni de resolver controversias entre partes.

${ }^{68}$ Como reflexiona Roxin en relación al sistema alemán -reflexión plenamente aplicable al nuestro-, el Ministerio Público no es un agente ejecutor de la jurisdicción, sino su par, en igualdad de condiciones, en la administración de justicia, y en esta posición, es llamado a efectuar un juicio jurídico independiente. Roxin, Claus, Posición jurídica y tareas futuras del Ministerio Público, en MAIER, Julio (compilador), El Ministerio Público en el proceso penal (Buenos Aires, Ad Hoc, 2000), p. 48.

${ }^{69}$ Ferrajoli, L., cit. (n. 12), p. 168, admite que "la frontera entre poder de verificación y poder de disposición, entre espacios irreductibles y espacios reducibles de discrecionalidad decisionaria, entre modelo garantista de derecho penal mínimo y modelos no garantistas de derecho penal tendencialmente máximo, no puede ser, evidentemente, trazada de manera rígida y precisa". Grafica la dificultad para trazar esta frontera ZAGREBELSKY, V., cit. (n. 21), p. 118, con el siguiente ejemplo: "se puede pensar en un cuadro probatorio inicialmente muy incierto y susceptible de modificarse sólo a consecuencia de una compleja actividad de investigación de la prueba, que podría derivar de una larga y costosa actividad - por ejemplo pericial-, la cual no puede ser valorada a priori sino en referencia a sus resultados. En la extrema incertidumbre de las perspectivas de la instrucción, el balance entre costo y duración de las investigaciones, y pequeñez o modestia del episodio del delito que se hipotetiza, lleva a menudo a solicitudes de decretos relativos al artículo 74 del Código de Procedimiento Penal [cuando el ministerio público considera que la denuncia de un delito es infundada, o que en todo caso no puede procederse]. Sin poder excluir que tal conducta pueda lograr cubrir abu- 


\section{El entorpecimiento al derecho de defensa que conlleva una aguda inter- vención judicial.}

Corolario del esquema acusatorio por el que se ha inclinado nuestro legislador, es que el sujeto pasivo de la persecución pasa a ser una parte necesaria del proceso desde la instrucción -si su identidad está determinada por cierto-, instancia desde la cual ya puede articular y maquinar la defensa que desplegará posteriormente en el juicio ${ }^{70}$. Como discurre Baumann, en el proceso acusatorio el imputado ya no tiene la posición de objeto de una inquisitio sino de sujeto procesal y contrincante del Fiscal, contra el cual puede arremeter enérgicamente sin temer los inconvenientes y la parcialidad del Juez, lo que le permite enfrentársele en una posición de mayor libertad jurídica $^{71}$.

Lo anterior demanda entonces reconocer de una vez por todas el adecuado sitial, dentro de la actividad de las partes, al derecho de defensa en su aspecto sustantivo, esto es, su derecho subjetivo para decidir libremente la estrategia procesal que mejor conviene a sus intereses con el objeto de neutralizar la argumentación opuesta ${ }^{72}$. Imprescindible es hoy para una adecuada y efectiva defensa la habilidad del letrado para negociar legítimamente con la Fiscalía alguna salida o procedimiento alternativo, así como para aprovechar la negligencia de ésta en la promoción de la persecución. La defensa no tiene ningún deber de objetividad ni de alcanzar la verdad en el proceso si ella es perjudicial para los intereses de su asistido. Como se ha expresa con acierto, "el defensor no es un auxiliar del juez ni de la justicia. Esto sólo se podría afirmar en un sentido figurado o metafórico. Sin embargo, esta frase -tan famosa como inexacta- ha contribuido a distorsionar la figura del defensor y la imagen del propio proceso. En el fondo, se trata de una pervivencia del sistema inquisitivo, donde se entendía que los imputados -generalmente 'brujas' o 'herejes' - no tenían derecho a una verdadera defensa, y que el defensor tenía un compromiso con la verdad y con la religión antes que con su propio cliente. Esta forma de pensar, obviamente, no tiene relación algu-

sos, es necesario concordar que ésta aparece extremadamente razonable, pero hay que reconocer también que la elección es ampliamente discrecional en cuanto a detenerse en la fase inicial del procedimiento o bien proseguir en el intento de integrar la prueba y, sólo después de una compleja actividad, someter el resultado a la decisión del juez".

${ }^{70}$ Maturana, C. - Montero, R., cit. (n. 19), I, p. 108, precisan que "complementa el principio acusatorio, y lo refuerza el establecimiento de un órgano especial encargado de la defensa del imputado, sin perjuicio del derecho de éste de contar con un defensor particular".

${ }^{71}$ Baumann, J., cit. (n. 22), p. 49.

${ }^{72}$ Aguilera, E., cit. (n. 18), p. 252. En su cara formal, presupone el deber del Estado de asegurar que no se produzcan obstáculos legales o externos al inculpado, de tal modo que éste pueda llevar a cabo su labor de resistencia durante todo el iter procesal. 
na con lo que significa un Estado republicano de Derecho. Según nuestro régimen constitucional, el defensor es un asistente directo del imputado; en tal carácter, debe guiarse por los intereses y necesidades de la defensa de su cliente. No cumple una función pública, sino que asesora a una persona en particular. Su misión y su actuación conforme a las reglas éticas, debe ceñirse a defender los intereses de ese imputado. En la medida en que lo haga, el defensor estará contribuyendo a que ese proceso responda a las exigencias del Estado de Derecho; y en esto último consiste su función 'pública' o 'social': su contribución, a través de la asistencia al imputado particular, a la legitimidad de los juicios en un Estado de Derecho"73.

Por ende, cada vez que Fiscalía y la defensa e imputado alcanzan un acuerdo, en el que éste ha renunciado al juicio oral, sea sometiéndose a una salida o procedimiento alternativo, por estimar que esa opción es la que mejor se aviene a su estrategia de defensa, la que por cierto ha tenido en cuenta la pasividad o incluso la ineptitud del Fiscal para configurar un delito de mayor gravedad al pasar por alto antecedentes investigativos o una determinada calificación jurídica ${ }^{74}$, sin duda que la desestimación del tribunal de dichos acuerdos deteriora y entorpece el derecho de defensa del imputado, pues el letrado que lo representa ya no tiene sólo como contradictor al Fiscal, sino también al órgano jurisdicente ${ }^{75}$. Y esta conclusión no cambia si el juez se

${ }^{73}$ Binder, A., Introducción, cit. (n. 10), p. 159. En la cultura legal estadounidense se destaca que los defensores no tienen una obligación equivalente a las que pesan sobre el Fiscal en la búsqueda de la justicia, con lo que el abanico de tácticas a su alcance es mucho menos limitado que para éstos, cfr. Pizzı, W., Juicios, cit. (n. 17), pp. 163-164. Gershman, B., cit. (n. 21), p. 10, en la misma línea, precisa que el abogado defensor no defiende una justicia abstracta, sino es un "Champion of the Defendant". En Alemania, en la contraposición de las "teoría del órgano" - donde el defensor es un órgano independiente de la administración de justicia que se encuentra a su lado como ayudante- y la "teoría de los intereses" - la cual sostiene que es función del defensor ayudar por derecho propio al imputado en la salvaguarda de intereses individuales-, Roxin, C., Derecho procesal, cit. (n. 4), p. 135, estima que "el defensor está llamado exclusivamente a hacer valer los intereses de defensa del imputado, legitimados por la ley, y en esa función es órgano de la administración de justicia, con lo cual se suprimiría la contradicción de las teorías en una síntesis más elevada”. Para un estudio de la naturaleza jurídica de las funciones desempeñadas por el abogado defensor, véase: Carocca Pérez, A., Garantía constitucional de la defensa procesal (Barcelona, Bosch, 1998), pp. 500 ss.

${ }^{74}$ Con razón se ha sostenido por RodRíGuez, N., cit. (n. 21), p. 121, que "la defensa tiene que buscar el mal menor para su cliente, incluso aprovechándose de un error cometido por la acusación al calificar, evaluar el posible resultado favorable o desfavorable de la realización de las pruebas que se pueden llevar a cabo y decidirse si conformarse con la acusación que le es solicitada o proseguir con la celebración del juicio”.

${ }^{75}$ Gimeno Sendra, Vicente, Los procedimientos penales simplificados. (Principio de oportunidad y proceso penal monitorio), p. 15 [visible en internet: www.mjusticia. 
escuda para actuar así en la mayor protección o garantía que para el imputado significa someter la decisión del asunto a un juicio oral, pues ese dictamen sólo lo puede emitir quien conoce todas las circunstancias que se podrían revelar en el juicio oral y que el registro de la investigación preliminar no demuestra, esto es, el imputado y su defensa, de manera que cuando el juez hace prevalecer su criterio por sobre el de éstos en cuanto a cuál es el camino procesal más conveniente para el acusado, simplemente está desoyendo la prohibición de "impedir, restringir o perturbar la debida intervención del letrado" proclamada en el artículo $19 \mathrm{~N}^{\circ} 3$ inciso $2^{\circ} \mathrm{CPol} .{ }^{76}$, y vulnerando su derecho a la autodefensa y a elegir libremente su defensa técnica, reconocido en el artículo 102 CPP., pues el juez les sustituye en su función dentro del proceso e impone su opinión -como ya dijimos, con un somero saber de los pormenores del caso-, especialmente por encima de la del asesor jurídico, que para tomar esas decisiones, ha designado el imputado ${ }^{77}$.

gob.es], en relación a los procedimientos penales simplificados indica que el fundamento de estas fórmulas de autocomposición procesal penal hay que encontrarlo en una de las posibles manifestaciones del derecho de defensa, cuyo ejercicio puede, en ocasiones, requerir el voluntario sometimiento a una determinada sanción o cumplimiento de una prestación, a fin de evitar los resultados inciertos del juicio oral en el que se puede irrogar una pena superior o más grave al acusado. En el mismo sentido CAROCCA, A., Garantía constitucional, cit. (n. 73), pp. 476-477, en relación a la conformidad del proceso español, señala que en ella no existe "renuncia" sino "ejercicio" del derecho fundamental de defensa, a diferencia de Alcalá-Zamora y Castillo, Niceto, El allanamiento en el proceso penal (Buenos Aires, Ediciones Jurídicas Europa-América, 1962), p. 129, para quien sí habría una renuncia del derecho de defensa. Aguilera, E., cit. (n. 18), p. 159, previene que, una cosa es sostener que el procedimiento de conformidad aludido es, en cuanto estrategia procesal de la que puede hacer uso el acusado, una manifestación o derivación del derecho de defensa, y, otra distinta, sustentar que ese derecho de defensa es la causa justificadora de las fórmulas autocompositivas.

${ }^{76}$ Sobre el tratamiento constitucional de este derecho a defensa jurídica, véase. Evans, E., cit. (n. 42), p. 142; y CARoccA, A., Las garantías constitucionales, cit. (n. 42), pp. 164-177.

${ }_{77}$ Como ha fundado Carocca, A., Garantía constitucional, cit. (n. 73), pp. 85 y 92-93, el "ejercicio" de la defensa no corresponde al órgano jurisdicente, y en consecuencia, rechaza la existencia de la llamada defensa material o defensa encomendada a los órganos jurisdiccionales. En ese orden, el JG debe asegurar al imputado la "posibilidad" de ir a juicio oral, como parte de su deber de garantizar su derecho de defensa, pero no forzarlo a esa instancia si se dan los presupuestos para otra forma de término que el imputado valora como más ventajosa, pues como precisa el mismo autor, pp. 190 ss., la garantía constitucional de la defensa -incluso en el proceso criminal- lo que realmente confiere es la "posibilidad" de intervenir en los procesos cuya resolución puede afectar a una persona, pero nunca impone una obligación de hacerlo. Siguiendo la jurisprudencia del Tribunal Constitucional español, el Tribunal Constitucional ha refrendado que: "Los requisitos que configuran el debido proceso penal diseñado por el legislador, se 
Así, tan válido como estrategia de defensa es aprovechar la no realización del Ministerio Público de una pericia esencial para el esclarecimiento del hecho dentro del plazo de investigación, o la no presentación de la acusación dentro de los 10 días desde el cierre de la investigación -situaciones que conducirían a la absolución o al sobreseimiento del caso, respectivamente-, como valerse de la no invocación por parte del Ministerio Público de hechos o calificaciones que le permiten acceder a salidas o procedimientos más convenientes para el imputado, por evitarle a éste la exposición a una sanción penal o sufrirla en un grado menor. Si el Tribunal en cualquiera de dichos ejemplos interviene activamente, ya sea para conceder un nuevo plazo para la presentación de la acusación como para exigir la formulación de la acusación por un delito más grave, en ambos salvaguarda la correcta aplicación de la ley penal, es cierto, pero nada menos que a cambio de un serio menoscabo del carácter acusatorio del proceso así como del derecho a defensa del inculpado.

En ese orden de ideas nos parece censurable la jurisprudencia proveniente de nuestra justicia ordinaria como constitucional, que no observa desmedro para el derecho de defensa en privar al imputado de la posibilidad de acceder a un procedimiento de juzgamiento alternativo al juicio oral, por estimar que éste constituye la mayor garantía para el encausado ${ }^{78}$, pasando por alto que la mejor estrategia para responder y enfrentar la persecución estatal no debe anticiparse abstractamente por el juez desde la altura de su estrado, altura que muchas veces le impide apreciar los pormenores del caso que tiene enfrente. Dicho diagnóstico, por tanto, es privativo de la defensa a la luz del caso concreto ${ }^{79}$.

agotan cuando los sujetos hacen uso de los derechos o deciden no hacerlo en las condiciones y plazos fijados por la ley" (sentencia rol No 986-207, de 30 de enero de 2008, considerando $20^{\circ}$ ).

${ }^{78}$ Por ejemplo, la sentencia del Tribunal Constitucional, rol N ${ }^{\circ} 1481-09$ de 10 de mayo de 2011 (considerandos $8^{\circ}, 10^{\circ}$ y $13^{\circ}$ ).

${ }^{79}$ De Diego Díez, L., La conformidad, cit. (n. 32), p. 172, expone que la actividad del acusado, conformándose con la pena de mayor gravedad, es un ejercicio de autodefensa, una expresión de defensa personal o privada, "cuyo objetivo fundamental reside en despejar la incertidumbre que para él supone la realización del juicio oral. Se trata de "evitar un mal peor" que podría derivarse de la práctica de la prueba en el juicio oral y de la posterior modificación de la calificación acusadora; así como de eludir la pena adicional que la publicidad del juicio siempre ocasiona en su propia fama”. 


\section{BiBLIOGRAFÍA}

Aguilera Morales, Encarnación, El principio de consenso. La conformidad en el proceso penal español (Barcelona, Cedecs, 1998).

Alcalá-Zamora y Castillo, Niceto, El allanamiento en el proceso penal (Buenos Aires, Ediciones Jurídicas Europa-América, 1962).

Alvear, María Soledad, Los principios que dan consistencia al nuevo sistema de enjuiciamiento criminal, en AA.VV., El nuevo proceso penal chileno (Concepción, Universidad de Concepción, Facultad de Ciencias Jurídicas y Sociales, Dept. de Derecho Procesal, 2000).

Ambos, Kai - Woischnik, Jan, Las reformas procesales penales en América Latina, en MAIER, Julio y otros (coordinadores), Las reformas procesales penales en América Latina (Buenos Aires, Ad Hoc, 2000).

ANDRÉs IbÁÑEZ, Perfecto, El Ministerio Fiscal entre "viejo" y "nuevo" proceso, en Revista de Ciencias Penales (1990-1993), número especial: "Ministerio Público”.

Andrés Ibáñez, Perfecto, Por un Ministerio Público “dentro de la legalidad”, en Nueva Doctrina Penal (Buenos Aires, Editores del Puerto, 1998), 1998/B.

Armenta Deu, Teresa, Criminalidad de bagatela y principio de oportunidad: Alemania y España (Barcelona, PPU, 1991).

Armenta Deu, Teresa, Principio acusatorio y Derecho penal (Barcelona, Bosch, 1995).

Asencio Mellado, José María, Principio acusatorio y derecho de defensa en el proceso penal (Madrid, Trivium, 1991).

Barros, Luis - Frühling, Hugo - García, Gonzalo - Quintana, Augusto - Sán$\mathrm{CHEZ}$, Domingo, El proceso penal chileno y su protección de los derechos del imputado, en Proceso penal y derechos fundamentales (Corporación Nacional de Reparación y Reconciliación, Colección Estudios, Santiago, 1994), I.

Baumann, Jürgen, Derecho procesalpenal. Conceptos fundamentalesy principiosprocesales (traducción castellana de C. A. Finzi, Buenos Aires, Depalma, 1986).

Bettiol, Giuseppe, Instituciones de derecho penal y procesal (traducción castellana de Gutiérrez-Alviz y Conradi, Barcelona, Bosch, 1977).

BINDER, Alberto M., Crisisy transformación de la justicia penal en Latinoamérica, en AA. VV., Reformas procesales en América Latina (Santiago, Corporación de Promoción Universitaria, 1993).

BINDER, Alberto M., Ideas y materiales para la reforma de la justicia penal (Buenos Aires, Ad Hoc, 2000).

BINDER, Alberto M., Introducción al Derecho procesal penal (2a edición, Buenos Aires, Ad Hoc, 2004).

Binder, Alberto, Funciones y disfunciones del Ministerio Público penal, en Bustos Ramírez, Juan (director), El Ministerio Público (Santiago, ConoSur, 1995).

Bofill GenzsCh, Jorge, Alcance de la obligación del fiscal de registrar sus actuaciones durante la investigación. Consecuencias de su incumplimiento en las diferentes etapas del procedimiento, en Revista de Estudios de la Justicia, 6 (2005).

Bofill Genzsch, Jorge, El juicio oral. Preparación y desarrollo, en AA.VV., El nuevo proceso penal chileno (Concepción, Universidad de Concepción, Facultad de Ciencias Jurídicas y Sociales, Dept. de Derecho Procesal, 2000).

Bovino, Alberto, La persecución penal pública en el derecho anglosajón, en Revista Latinoamericana de Politica Criminal, 2 (1997). 
Bovino, Alberto, Problemas del derecho procesal penal contemporáneo (Buenos Aires, Editores del Puerto, 1998).

Bustos Ramírez y otros, Elproceso penal chileno, en Procesopenaly derechos fundamentales (Santiago, Corporación Nacional de Reparación y Reconciliación, Colección Estudios, 1994), I.

Cabezudo Rodríguez, Nicolás, El Ministerio Público y la justicia negociada en los Estados Unidos de Norteamérica (Granada, Comares, 1996).

Cafferata Nores, José, Cuestiones actuales sobre el proceso penal ( $3^{\mathrm{a}}$ edición, Buenos Aires, Editores del Puerto, 2000).

Carnelutti, Francesco, La prueba civil (traducción castellana de N. Alcalá-Zamora y Castillo, Buenos Aires, Arayú, 1955).

Carocca Pérez, Alex, El nuevo sistema procesal penal ( $3^{a}$ edición, Santiago, LexisNexis, 2005).

Carocca Pérez, Alex, Garantía constitucional de la defensa procesal (Barcelona, Bosch, 1998).

Carocca Pérez, Alex, Las garantías constitucionales en el sistema procesal chileno, en Ius et praxis, 3 (1997) 2.

Castro Vargas, Carlos, Resabios inquisitivos en el proceso penal chileno (Santiago, Metropolitana, 2010).

Cerda San Martín, Rodrigo - Hermosilla Iriarte, Francisco, El Código Procesal Penal. Comentarios, concordanciasy jurisprudencia ( $2^{a}$ edición, Santiago, Librotecnia, 2006).

Chahuán Sarrás, Sabas, Manual del nuevo procedimiento penal ( $3^{a}$ edición, Santiago, LexisNexis, 2007).

Clariá Olmedo, Jorge, Derecho procesal penal (Buenos Aires, Rubinzal-Culzoni, s.d.) I.

Couso Salas, Jaime, Oportunidad versus legalidad: entre economia político-criminal, despenalización, prevención y principios garantistas, en Cuadernos de Análisis Jurídico, 39 (1998).

Damaska, Mirjan R., Evidence Law Adrift (New Haven - London, Yale University Press, 1997).

Damaska, Mirjan, Las caras de la justicia y el poder del Estado. Análisis comparado del proceso civil (traducción castellana de A. Morales Vidal, Santiago, Editorial Jurídica de Chile, 2000).

De Diego Díez, Luis Alfredo, El principio "el que instruye no debe juzgar" como garantía de imparcialidad en el enjuiciamiento penal, ahora, en AA.VV., Crisis de la justicia y reformas procesales (Madrid, Centro de Publicaciones, Ministerio de Justicia, 1988).

De Diego Díez, Luis Alfredo, La conformidad del acusado (Valencia, Tirant lo Blanch, 1997).

DE la BARRA, Rodrigo, Sistema inquisitivo versus adversarial. Cultura legaly perspectivas de la Reforma Procesal en Chile, en Ius et Praxis, 5 (1999) 2.

De La Oliva Santos, Andrés y otros, Derecho procesalpenal (4a edición, Madrid, Ed. Centro de Estudios Areces, 1999).

Del Río FerRetti, Carlos, Dosformas discutibles deponer en duda el carácter cognoscitivo de la aplicación judicial del derecho penal: El principio del consenso y la garantía de la no agravación punitiva, en Revista de Derecho de la Pontifica Universidad Católica de Valparaiso, 34 (2010). 
Del Río Ferretti, Carlos, El principio del consenso de las partes en el proceso penal y enjuiciamiento jurisdiccional: aclaraciones conceptuales necesarias, en Revista Chilena de Derecho, 35 (2008) 1.

Del Río Ferretti, Carlos, Los poderes de decisión del juez penal. Principio acusatorio $y$ determinadas garantías procesales (el deber de correlación) (Santiago, Editorial Jurídica de Chile, 2009).

Del Río Ferretti, Carlos, Proceso penal, consenso de las partes y enjuiciamiento jurisdiccional (Santiago, Librotecnia, 2009).

Delgado BARrio, Javier, El principio de oportunidad en el proceso penal, ahora, en, AAVV., La Reforma del Proceso Penal. II Congreso de Derecho Procesal de Castilla y León (Madrid, Ministerio de Justicia, 1989).

Delmas-Marty, Mireille (directora), Procesos Penales de Europa (traducción castellana de P. Morenilla A., Zaragoza, Edijus, 2000).

Díez-Picazo, Luis, El poder de acusar, Ministerio Fiscal y Constitucionalismo (Barcelona, Ariel, 2000).

Duce, Mauricio - Riego, Cristián, Proceso penal (Santiago, Editorial Jurídica de Chile, 2009).

Esmein, A., A History of Continental Criminal Procedure. With special reference to France (Boston, Little Brown and Company, 1913).

Evans De la CuAdra, Enrique, Los derechos constitucionales (2a edición, Santiago, Editorial Jurídica de Chile, 1999), II.

FAIRÉn Guillén, Víctor, Doctrina general del proceso penal. (Hacia una teoría y Ley procesal generales) (Barcelona, Bosch, 1990).

Fernández González, Miguel Ángel, El derecho constitucional al debido proceso con especial aplicación al nuevo proceso penal, en Anales de la Facultad de Derecho. Universidad de Chile, 2 (2005).

Fernández GonzÁlez, Miguel Ángel, La nueva justicia penal frente a la Constitución (Santiago, LexisNexis, 2006).

Ferrajoli, Luigi, Derecho y razón. Teoría del garantismo penal ( $5^{\mathrm{a}}$ edición, Madrid, Trotta, 2001).

Ferrer Beltrán, Jordi, La valoración racional de la prueba (Madrid, Marcial Pons, 2007).

Gandulfo, Eduardo, Principios del Derecho procesal penal en el nuevo sistema de procedimiento chileno, en Revista de Derecho de la Universidad Católica de Valparaíso, 20 (1999).

García de Enterría, Eduardo - Fernández, Tomás Ramón, Curso de Derecho administrativo (12a edición, Madrid, Thomson-Civitas, 2004), I.

Gascón Abellán, María, Los hechos en el Derecho. Bases argumentales de la prueba ( $3^{a}$ edición, Madrid, Marcial Pons, 2010).

Gershman, Bennett L., The Prosecutor as a "Minister of Justice", en N.Y. St. B.J., 60 (1988).

Gimeno Sendra, Vicente - Moreno Catena, Víctor - Cortés Domínguez, V., Derecho procesal penal ( $3^{\text {a }}$ edición, Madrid, Colex, 1999).

Gimeno Sendra, Vicente, Los procedimientospenales simplificados. (Principio de oportunidad y proceso penal monitorio)[visible en internet: www.mjusticia.gob.es].

Goldschmidt, James, Problemas jurídicos y politicos del proceso penal (Barcelona, Bosch, 1935). 
Goldstein, Abraham, Reflections on Two Models: Inquisitorial Themes in American Criminal Procedure, en Stanford Law Review, 26 (mayo de 1974).

Goldstein, Abraham, The Passive Judiciary. Prosecutorial Discretion and the Guilty Plea (s. l., Louisiana State University Press, 1981).

Gómez Colomer, Juan Luis, El proceso penal alemán. Introducción y normas básicas (Barcelona, Bosch, 1985).

Gómez Colomer, Juan Luis, El proceso penal en el Estado de Derecho. Diez estudios doctrinales (Lima, Palestra Editores, 1999).

Gómez Colomer, Juan-Luis, El Ministerio Fiscal ¿Eje de la reforma procesal penal? en Picó I Junoy, Joan (director), Problemas actuales de la justicia penal (Barcelona, Bosch, 2001).

Gómez Orbaneja, Emilio - Herce Quemada, Vicente, Derecho procesalpenal (10a edición, Madrid, Artes Gráficas y Ediciones, 1987).

Hart, Herbert. L. A., El concepto de Derecho (traducción castellana de G. R. Carrió, Buenos Aires, Abeledo-Perrot, 1992).

Horvitz Lennon, María Inés - López Masle, Julián, Derecho procesal penal chileno (Santiago, Editorial Jurídica de Chile, 2005).

Horvitz Lennon, María Inés, Algunas formas de acuerdo o negociación en el proceso penal: tendencias del derecho comparado, en Revista Ciencias Penales, 40 (1994) 2.

Horvitz Lennon, María Inés, Ministerio Público y selectividad, en Pena y Estado. Revista Latinoamericana de Politica Criminal, 2 (1997) 2.

Hoyos de la BArrera, María Teresa, Principios fundamentales del nuevo proceso penal, en Revista de Derecho Procesal, 20 (2005).

Kühne, Hans-Heiner, Germany, en Van Den Wyngaert, Christine (editora), Criminal Procedure Systems in the European Community (London y otras, 1993).

Lafave, Wayne y otros, Criminal Procedure (5a edición, s. l., West, 2009).

Langbein, John, The Origins of Adversary Criminal Trial (Oxford, N.Y, Oxford University Press, 2005).

LANGer, Máximo, From Legal Transplants to Legal Translations: The Globalization of Plea Bargaining and the Americanization Thesis in Criminal Procedure, en Harvard International Law Journal, 45 (invierno de 2004), pp. 1-64.

LANGER, Máximo, La dicotomia acusatorio-inquisitiva y la importación de mecanismos procesales de la tradición jurídica anglosajona. Algunas reflexiones a partir del procedimiento abreviado, en HENDLER, Edmundo (compilador), Las garantías penales $y$ procesales. Enfoque histórico-comparado (Buenos Aires, Editores del Puerto, 2004).

Lynch, Gerard E., Prosecution: Prosecutorial Discretion, en Dressler, Joshua (editor), Encyclopedia of Crime \& Justice (2a edición, MacMillan Reference USA, New York, 2002) III.

MAIER, Julio, Democracia y administración de justicia penal en Iberoamérica, en AA.VV., Reformas procesales en América Latina (Santiago, Corporación de Promoción Universitaria, 1993).

MaIER, Julio, Derecho procesal penal argentino (Buenos Aires, Hammurabi, 1989), I, vol. B.

MaIer, Julio, Derecho procesal penal. Parte general. Sujetos procesales (Buenos Aires, Editores del Puerto, 2003), II.

Martín Pastor, José, El Ministerio Fiscal como director de la investigación oficial en el proceso penal (Bolonia, Publicaciones del Real Colegio de España, 2005). 
Maturana Miguel, Cristian - Montero López, Raúl, Derecho procesal penal (Santiago, LegalPublishing, 2010), II.

Mera Figueroa, Jorge, Discrecionalidad del Ministerio Público, calificación jurídica $y$ control judicial, en Informe de Investigación $N^{o} 1$ al 15, 1999-2003 (Santiago, Centro de Investigaciones Jurídicas, Facultad de Derecho Universidad Diego Portales, 2004).

Mercedes Alliaud, Alejandra, Principio acusatorio. Estudio histórico-comparado de su génesis y evolución, ahora, en HENDLER, Edmundo (compiladores), Las garantías penales y procesales. Enfoque histórico-comparado (Buenos Aires, Editores del Puerto, 2004).

Montero Aroca y otros, Derecho jurisdiccional. Parte general (2 ${ }^{\mathrm{a}}$ edición, Barcelona, Bosch, 1989), I.

Montero Aroca, Juan y otros, Derecho jurisdiccional. Proceso penal (Barcelona, Bosch, 1991), III.

Moreno Catena, Víctor y otros, Introducción al Derecho procesal (2a edición, Madrid, Colex, 1997).

Moreno Catena, Víctor, El enjuiciamiento de delitos menos graves. Apunte sobre la imparcialidad del juzgador, en Boletín de Información del Ministerio de Justicia, 1468 (1987).

Moreno Catena, Víctor, Presente y futuro del proceso penal español, en Revista de Derecho y Jurisprudencia, 96 (1999) 2.

Muñoz Machado, Santiago, Tratado de Derecho administrativo y Derecho público general (Madrid, Thomson-Civitas, 2004), I.

NúÑez VÁsQuez, J. Cristóbal, Tratado del proceso penal y del juicio oral (Santiago, Editorial Jurídica de Chile, 2003), II.

Ortells Ramos, Manuel, Cuatro aproximaciones al nuevo proceso penal chileno desde la perspectiva del proceso penal en paises de la Unión Europea, en AA. VV., El nuevo proceso penal chileno (Concepción, Facultad de Ciencias Jurídicas y Sociales. Dpto. de Derecho Procesal. Universidad de Concepción, 2000).

Ortells Ramos, Manuel, La instrucción por el Ministerio Público (Reflexiones sobre el estado de la cuestión en Derecho español) (Ponencia en Seminario internacional 'Justicia y sociedad', organizado por el Instituto de Investigaciones Jurídicas de la UNAM y por la Procuraduría General de la República, México, UNAM, 1994).

Otero Lathrop, Miguel, El Ministerio Público, en AA.VV., El nuevo proceso penal chileno (Concepción, Universidad de Concepción, Facultad de Ciencias Jurídicas y Sociales, Departamento de Derecho Procesal, 2000).

Piedrabuena Richard, Guillermo, Jurisprudencia del Tribunal Constitucional sobre normas del Código Procesal Penal, en Revista Chilena de Derecho. Consejo de Defensa del Estado, 21 (junio de 2009).

Piedrabuena Richard, Guillermo, Rol del Ministerio Público en el nuevo proceso penal, en Revista Chilena de Derecho, 30 (2003) 1.

PizzI, William T., Juicios y mentiras (traducción de C. Fidalgo Gallardo, Madrid, Tecnos, 2004).

PizzI, William, Understanding Prosecutorial Discretion in the United States: The Limits of Comparative Criminal Procedure as an Instrument of Reform, en Obio St. L.J., 54 (Fall, 1993).

Prieto-Castro, Leonardo - Gutiérrez de Cabiedes, Eduardo, Derecho procesal penal (2a edición, Madrid, Tecnos, 1982). 
Rivadeneira, Ricardo, El Ministerio Público y su contribución a la capacidad de investigación del sistema procesal penal, en AA.VV., El Ministerio Público para una nueva justicia criminal (Santiago, Fundación Paz Ciudadana - Escuela de Derecho, Universidad Diego Portales - Corporación de Promoción Universitaria, 1994).

Rodríguez García, Nicolás, El consenso en el proceso penal español (Barcelona, JMB, 1997).

Roxin, Claus, Derecho procesal penal (traducción castellana de G. Córdoba y D. Pastor, Buenos Aires, Editores del Puerto, 2000).

Roxin, Claus, Posición jurídica y tareas futuras del Ministerio Público, en MAIER, Julio B. (compilador), El Ministerio Público en el proceso penal (Buenos Aires, Ad Hoc, 2000).

Ruiz Vadillo, Enrique, Estudios de Derecho procesal penal (Granada, Comares, 1995).

Rusconi, Maximiliano, División de poderes en el proceso penal e investigación a cargo del ministerio público, en AA.VV., El Ministerio Público en el proceso penal (Buenos Aires. Ad Hoc, 2000).

Salas Astrain, Jaime, Problemas del proceso penal (Santiago, Librotecnia, 2009).

Sánchez Morón, Miguel, Discrecionalidad administrativa y control judicial (Madrid, Tecnos, 1994).

SCHÜNEMANN, Bernd, ¿Crisis del procedimiento penal? (¿marcha triunfal del procedimiento penal americano en el mundo?), en EL MISMO, Temas actuales y permanentes del Derecho penal después del milenio (Madrid, Tecnos, 2002).

Serra Domínguez, Manuel, Estudios de Derecho procesal (Barcelona, Ariel, 1969).

Silva Bascuñán, Alejandro, Tratado de Derecho constitucional (2a edición Santiago, Editorial Jurídica de Chile, 2002), VIII.

Solari Peralta, Tito, Presupuestosteóricos del Ministerio Público, en Revista de Derecho de la Universidad Católica de Valparaíso, 20 (1999).

Soto Piñeiro, Miguel, Ministerio Público y política criminal, en AA.VV., El Ministerio Público para una nueva justicia criminal (Santiago, Fundación Paz Ciudadana - Escuela de Derecho, Universidad Diego Portales - Corporación de Promoción Universitaria, 1994).

TARuffo, Michele, La prueba de los hechos (traducción castellana de J. Ferrer Beltrán, Madrid, Trotta, 2002).

Tavolari, Raúl, Instituciones del nuevo proceso penal. Cuestiones y casos (Santiago, Editorial Jurídica de Chile, 2005).

Verdugo Marinkovic, Mario - Pfeffer Ureuiaga, Emilio - Nogueira Alcalá, Humberto, Derecho constitucional ( $2^{a}$ edición, Santiago, Editorial Jurídica de Chile, 1999), II.

Zagrebelsky, Vladimir, Independencia del Ministerio Público y obligatoriedad de la acción penal, en Revista de Ciencias Penales (1990-1993), número especial: "Ministerio Público". 